\title{
Assessment of Diversity in the Genus Ficus L. (Moraceae) of Katerniaghat Wildlife Sanctuary, Uttar Pradesh, India
}

\author{
Anoop Kumar, Omesh Bajpai, Ashish K. Mishra, Nayan Sahu, Soumit K. Behera, L. B. Chaudhary \\ Plant Biodiversity \& Conservation Biology Division, National Botanical Research Institute (CSIR), Rana Pratap Marg, Lucknow, \\ India. \\ Email: dr_lbchaudhary@rediffmail.com
}

Received February $14^{\text {th }}, 2011$; revised March $7^{\text {th }}, 2011 ; \quad$ accepted March $16^{\text {th }}, 2011$.

\begin{abstract}
The paper deals with the taxonomy and diversity within the genus Ficus occurring in Katerniaghat Wildlife Sanctuary based on extensive field and herbarium studies. The genus comprises 11 species in the study area contrary to the earlier report of 8 species. Out of which, one species each belongs to herbs (F. assamica) and straggling shrubs (F. heterophylla) and the remaining species to shrub to big free standing trees (F. benghalensis, F. hispida, F. palmata subsp. virgata, F. racemosa, F. religiosa, F. retusa var. nitida, F. rumphii, F. semicordata and F. squamosa). F. microcarpa and F. carica have been excluded as they do not occur in the sanctuary but reported in the previous work due to misidentification. F. repens has been segregated from F. heterophylla and reinstated as a distinct species with a correct name F. assamica. F. retusa var. nitida forms a new record for the sanctuary. In overall gross morphology, F. hispida, F. palmata subsp. virgata, F. assamica and F. heterophylla exhibit maximum diversity especially in their leaves, peduncles and figs. Among all species F. hispida has been found more common especially in low land and moist areas in mixed forest whereas F. retusa var. nitida has been seen with only two plants. All species have been critically examined and provided with correct nomenclature, vernacular name, description, phenology, ecology, uses and reference to voucher specimens. A dichotomous bracketed key to the species along with line drawings has also been included for identification.
\end{abstract}

Keywords: Ficus, Taxonomy, Diversity, Katerniaghat Wildlife Sanctuary, Moraceae

\section{Introduction}

Wildlife sanctuary plays an important role in the conservation of plants as well as animals diversity. The forest of Katerniaghat was declared as wildlife sanctuary in 1975 by government of India. Katerniaghat Wildlife Sanctuary (KWS), a moist deciduous forest in the Upper Gangetic Plains of Bahraich district in the province of Uttar Pradesh, India is situated between $27^{\circ} 41^{\prime}-27^{\circ} 56^{\prime} \mathrm{N}$ $\& 81^{\circ} 48^{\prime}-81^{\circ} 56^{\prime} \mathrm{E}$ with elevation ranges from 116-165 m along the southern border of the Himalayan kingdom Nepal. It is a dense patch of $40 \mathrm{~km}$ long and $10 \mathrm{~km}$ wide with an area of $440 \mathrm{~km}^{2}$ which has been divided into five zones. Since the sanctuary was not thoroughly explored in the past, the entire area has been selected to assess the plant diversity available there, so that any conservation programme required in the future could be implemented in proper way. The present study which highlights the taxonomy and diversity of the genus Ficus L. available within the sanctuary area forms a small part of the entire flora. The extensive survey and collection of the plants since last two years reveal that as far as the number of species is concerned the genus Ficus L., commonly know as 'Fig', is the largest genus in the sanctuary area and plays important role in the forest ecosystem being a keystone species. During investigation some identification and nomenclatural problems were also encountered within the species of Ficus occurring there.

Ficus is considered most conspicuous but problematic genus due to its minute flowers present inside the closed fleshy receptacle (i.e. scyconium). The genus comprises about 750 species throughout the world (Corner [1,2]; Berg [3]; Berg \& Corner [4]; Ronsted et al. [5,6]) and about 120 species in India (King $[7,8]$ ). In the present 
study 11 species of Ficus have been reported from the study area contrary to the earlier report of 8 species (Maliya \& Datt [9]; Khanna et al. [10])). Even in the previous works also only 7-8 species of Ficus were recorded from the entire Bahraich district (Saini [11]; Panigrahi et al. [12]) in which the sanctuary area falls. Although, Ficus microcarpa L. f. has been reported by Panigrahi [12] from sanctuary area (Nishangarha range), however, the same was not noticed in the present study. The voucher specimen of Ficus microcarpa L. f. was also not traced out at BSA where Panigrahi et al. [12] have deposited their specimens. In the sanctuary area $F$. palmata subsp. virgata is available, while the same has been identified as F. carica in previous work (Maliya \& Datt [9]). Ficus carica is a native of Western Asia and found in India only in cultivation. Further, Ficus repens is quite distinct from $F$. heterophylla hence, treated here separately with a correct nomenclature F. assamica. F. retusa var. nitida has been collected for the first time from the sanctuary.

Out of 11 species of Ficus recorded in the present study, one species each belongs to herbs (F. assamica) and straggling shrubs ( $F$. heterophylla) and the remaining species to shrub to big free standing trees $(F$. benghalensis, F. hispida, F. palmata subsp. virgata, F. racemosa, F. religiosa, F. retusa var. nitida, F. rumphii, $F$. semicordata and F. squamosa). F. palmata subsp. Virgata shows wide range of variations in its habit which range from small shrub to medium-sized tree. In overall gross morphology, F. palmata subsp. virgata, F. assamica and $F$. heterophylla exhibit maximum diversity especially in their leaves, peduncles and figs. The position of the development of figs and fig bearing peduncles are quite variable from plant to plant in F. semicordata. Among all species F. hispida has been found more common especially in low land and moist areas in mixed forest whereas $F$. retusa var. nitida has been seen with only two plants. The main associates of figs in the sanctuary area are: Bombax ceiba, Mallotus nudiflorus, Mallotus philippensis, Syzygium cumini, Miliusa tomentosa etc.

All species have been critically examined and detailed taxonomic information such as recently accepted botanical name with common synonyms, Hindi vernacular names, description, phenology, ecology, uses and reference to voucher specimens have been provided. A dichotomous bracketed key to the species along with line drawings has also been prepared for easy and quick identification. The voucher specimens of all species have been deposited at LWGfor future reference.

\section{Key to the Species}

1a) Young branches distinctly hollow; leaves opposite 2 1b) Young branches solid; leaves alternate 3

2a) Main trunk present; figs develop chiefly throughout main trunk; lateral bracts absent on fig body $\mathbf{4}$. F. hispida

2b) Main trunk absent, caespitose; figs develop chiefly at base of the plant; lateral bracts present on fig body $\mathbf{1 1}$. F. squamosa

3a) Figs develop on separate inflorescence axis in clusters 4

3b) Figs develop in the axils of leaves 5

4a) Inflorescence axis up to 6 feet long, chiefly develop surrounding base or in middle of trunk in cluster; leaf lamina quite rough on touch, obliquely semisagittate at base, serrate along margins; figs tomentose, brown wart like structure present on body, light pink at maturity; tepals 5 in female flowers, free, entire along margins $\mathbf{1 0 .}$ F. semicordata

4b) Inflorescence axis up to $25 \mathrm{~cm}$ long, chiefly develop throughout main trunk and branches in cluster; leaf lamina smooth on touch, rounded or cuneate at base, entire along margins; figs pubescent, brown wart like structure absent on body, red at maturity; tepals 3 in female flowers, jointed at base, irregularly dentate or serrate along margins 6 . F. racemosa

5a) Leaves dentate to serrate along margins 6

5b) Leaves entire along margins 8

6a) Petioles 5-10 mm long, quite shorter than leaf lamina; figs ellipsoide or globular with $0-3 \mathrm{~mm}$ long stipe 3. F. heterophylla

6b) Petioles 4-6 cm long, almost equal to leaf lamina; figs pyriform with 8-5 $\mathrm{mm}$ long stipe 7

7a) Herbs or small shrubs, $30-60 \mathrm{~cm}$ high; stem unbranched; lamina entire or up to 4-lobed, obliquely cordate base; pistillode flowers present; stamen in male flowers 11 . F. assamica

7b) Large shrubs or small trees, 1-3 m tall; stem branched; lamina entire, cordate at base; pistillode flowers absent; stamens in male flowers 3-5 5. F. palmata subsp. virgata

8a) Leaves thick in texture, obtuse at apex; aerial prop roots present and touch the ground $2 . \mathbf{F}$. benghalensis

8b) Leaves membranous in texture, acute to caudate at apex; aerial prop roots absent 9

9) Petioles up to $1 \mathrm{~cm}$ long, less than $1 / 3$ of the leaf lamina; lamina 7-9 $\times 3-4 \mathrm{~cm}$, elliptic or sometimes obovate, cuneate at base $\mathbf{. 8}$. F. retusa var. nitida

9b) Petioles $4-12.5 \mathrm{~cm}$ long, more than $1 / 3$ of the leaf lamina; lamina $11-18 \times 6-12.5 \mathrm{~cm}$, ovate to broadly ovate, truncate, obtuse or rounded at base $\mathbf{1 0}$

10) Leaf lamina, ovate, acuminate at apex; petioles 4-8 cm long; basal bracts 3; figs undepressed globose; gall and female flowers with 3 spatulate tepals $\mathbf{9}$. F. rumphii

10b) Leaf lamina broadly ovate, abruptly caudate at 
apex; petioles 9-12.5 cm long, basal bracts 4; figs depressed globose; gall and female flowers with 4-5 narrowly lanceolate tepals $\mathbf{7}$. F. religiosa

\section{Enumeration of the Species}

\subsection{Ficus Assamica}

Miq. in Hook. London J. Bot. 7: 226. 1848. F. repens Roxb. ex Willd., Sp. Pl. 4 (2): 1149. 1806 (non Rottl. 1803); Roxb., Fl. Ind. 3: 535. 1832; Wight, Icon. Pl. Ind. Orient. 2: t. 636. 1843; Brandis, Fr. Fl. N. W. \& C. India 424. 1874. F. heterophylla var. repens (Roxb. ex Willd.) King in Ann. Roy. Bot. Gard. Calcutta. 1: 77. 1888; Brandis, Indian Trees 606. 1906; Haines, Bot. Bihar \& Orissa 3: 877. 1922; Kanjilal, For. Fl. Pilibhit, Oudh, Gorakhpur \& Bundelkhand 365. 1933; Kanjilal \& Kanjilal, Fl. Assam 251. 1940. F. heterophylla f. repens (Roxb. ex Willd.) King in Hook.f., Fl. Brit. India 5: 519. 1888. F. heterophylla var. assamica (Miq.) Corner in Gard. Bull. Singapore 21: 73. 1965; Chater. in Hara et al. Enum. Fl. Pl. Nepal, 3: 210. 1982.

Herbs or small shrubs, $30-60 \mathrm{~cm}$ tall, erect or some of them gradually bend close to the ground or become creeper due to its weak elongated stem and body weight after the development of figs. Stem almost woody, dark brown towards base, yellowish-green towards apex, 3-5 $\mathrm{mm}$ in diam., narrowly hollow, mostly unbranched especially in erect forms, sparsely puberulous in young stage, glabrous or unevenly glabrescent at maturity; internodes (1.5-) 2.5-6.5 cm long; nodes adjoining to the soil produce roots. Stipules ca. $5 \times 2 \mathrm{~mm}$, deciduous, triangularlanceolate, truncate at base, entire and ciliate along margins, acute to acuminate at apex, scabrous outside only along middle region, glabrous inside. Leaves $11-12 \mathrm{~cm}$ long, alternate; lamina 7-9 × 5-6.7 cm, yellowish- green, ovate to broadly ovate, simple or up to 4-lobed, cordate and oblique at base, dentate along margins, acute at apex, scabrous above, tomentose below, subcoriaceous; midrib reaches up to apex; basal veins 1-3; secondary veins 3-4 pairs; petioles 4.2-5.7 cm long, scabrous. Receptacles 4.5-5.5 cm long, solitary, axillary, dioecious; peduncle 1.8-2.6 cm long, scabrous. Basal bracts 3, $1 \times 1 \mathrm{~mm}$, triangular, truncate at base, entire and hairy along margin, acute at apex, scabrous outside, glabrous inside. Fig body 2-2.3 $\times 1.3-1.5 \mathrm{~cm}$, pyriform, reddish-brown after ripening, scabrous, with red dots on surface, and pink ostioler opening; stipe 8-13 mm long, unevenly scabrous. Apical bracts 6 , minute, triangular, entire along margins, acute at apex, scabrous outside. Male flowers few, present near to ostioler opening, 2-3 mm long, subpedicellate; tepals 5, ca. $2 \mathrm{~mm}$ long, narrowly lanceolate, jointed only at extreme base, entire along margins, acute at apex, glabrous, hyaline; stamen 1, ca. $2 \mathrm{~mm}$ long; filament $1, c a .1 \mathrm{~mm}$
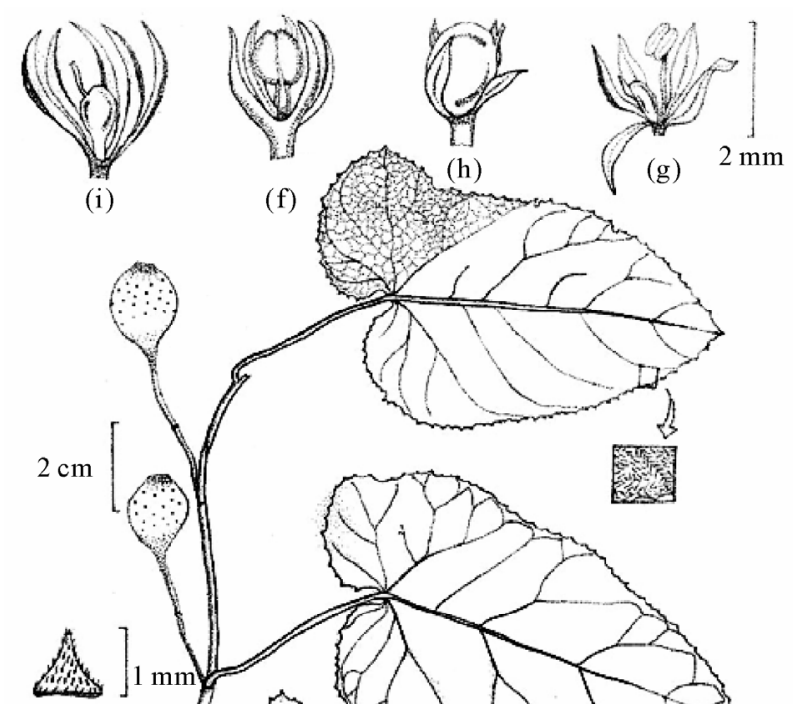

(f)

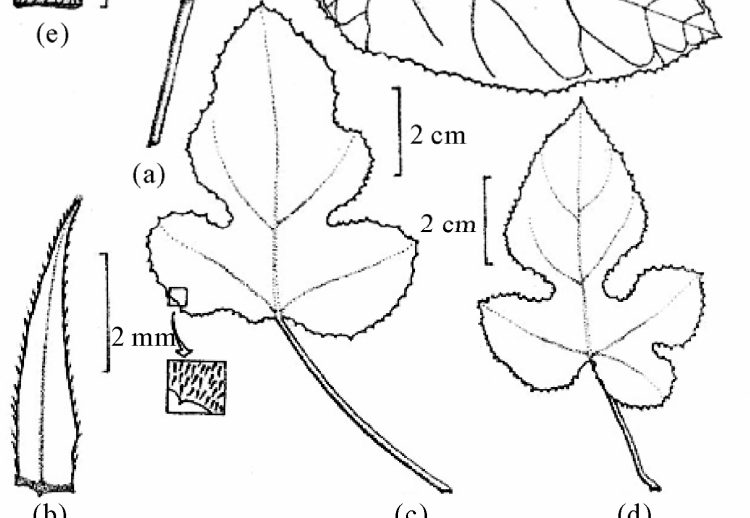

(b)

(c)

(d)

Figure 1. Ficus assamica Miq.: (a) Habit; (b) Stipule; (c)-(d) Leaves; (e) Basal bract; f. Male flower; g. Pistillode flower; (h) Gall flower; (i) Female flower (a)-(b) \& (e)-(i) from Chaudhary, Kumar \& Bajpai 250601; (c)-(d) from Chaudhary, Kumar \& Bajpai 252812).

long; anther ca.1mm long. Pistillode flowers numerous, present near to ostioler opening, $\mathrm{ca}$. $2 \mathrm{~mm}$ long, subsessile; tepals 5, ca. $2 \mathrm{~mm}$ long, narrowly lanceolate, entire along margins, acute at apex, sparsely hairy outside, glabrous inside, hyaline; stamen 1, ca. $2 \mathrm{~mm}$ long; filament ca. $1 \mathrm{~mm}$ long; anther 1, minute; ovary obovate, subsessile to sessile; style 1 , lateral, $0.5-1 \mathrm{~mm}$ long; slightly broaden. Gall flowers numerous, present throughout inside fig body, 2-3 $\times 1 \mathrm{~mm}$, pedicels $0.5-2 \mathrm{~mm}$ long; tepals 4, 1-2 mm long, narrowly lanceolate, jointed only at base, entire along margins, acute at apex, glabrous, pink to purple; ovary ca. $1.5 \times 1 \mathrm{~mm}$, pyriform or ovoid, with 0.5-1 mm long stalk; style lateral, minute; stigma normal. Female flowers ca. $3 \mathrm{~mm}$ long; tepals 5, ca. $2 \mathrm{~mm}$ long, linear-lanceolate, jointed below, free above, entire along margin, acute to acuminate at apex, glabrous, hyaline; ovary ca. $1 \mathrm{~mm}$, subsessile; style $c a .1 \mathrm{~mm}$, subterminal; stigma normal, slightly broadened. 
Flowering \& Fruiting: Mar. - Jul.

Distribution: India (Gangetic Plain: Uttar Pradesh, West Bengal, Assam), Nepal, Bangladesh, S. China (?), Indo-China (Laos, Vietnam).

Ecology: Occasional in moist and shady places among grasses.

Notes: In some of the earlier publications (Duthie [13]; Fischer [14]) this species was treated as a synonym under $F$. heterophylla while it distinctly differs in habit, leaf shape, base, lobation and texture, petiole length, figs bearing peduncle and fig shape \& colour. The species shows quite variations in leaf shape which ranges from entire to distinctly trilobed on the same plant or on separate plants in same population.

Specimens examined: Uttar Pradesh, Bahraich, Katerniaghat Wildlife Sanctuary: near Vardia Chauki, Katiyara, 08. 06. 2009, L. B. Chaudhary, A. Kumar \& O. Bajpai 250601 (LWG); 18. 07. 2009, L. B. Chaudhary, A. Kumar \& O. Bajpai 250811 (LWG); 21. 02. 2009, L. B. Chaudhary, A. Kumar \& O. Bajpai 250812 (LWG).

\subsection{Ficus Benghalensis}

L., Sp. pl. 1059.1753; King in Ann. Roy. Bot. Gard. Calcutta. 1: 18, t. 13 \& 81c.1887 \& in Hook.f., Fl. Brit. India 5: 499. 1888; Brandis, Indian Trees 600. 1906; Duthie, Fl. Upp. Gang. Pl. 3(1): 147. 1915; Corner in Gard. Bull. Singapore 17: 381. 1960; 21 (1): 14. 1965 \& in Dass \& Forsb., Rev. Handb. Fl. Ceylon 3: 251, f. 13. 1981; Panigrahi in Bull. Bot. Surv. India 11 (1\&2): 96. 1969; Srivastava, Fl. Gorakhpurensis 305. 1976; Singh, Fl. Dudhwa National Park 390. 1997; Berg \& Corner in Fl. Malesiana 17(2): 630. 2005; Saini in J. Econ. Taxon. Bot. 29 (4): 878. 2005; Maliya \& Datt in J. Econ. Taxon. Bot. 34 (1): 63. 2010. F. indica L., Sp. pl. 1060. 1753, non sensu King (1887); Roxb., Fl. Ind. 3: 539. 1832. F. umbrosa Salisb., Prodr. Stirp. Chap. Allerton 16. 1796. F. cotonaeifolia Vahl, Enum. Pl. 2: 189. 1806. Urostigma benghalense (L.) Gasp., Nov. Gen. Fic. 7. 1844; Wight, Icon. Pl. Ind. Orient. t. 1989. 1853.

Vernacular name: Bargad, Banyan.

Trees, erect often epiphytic at first, 30-40 m tall, evergreen, prop aerial roots arising from main trunk and branches; milky latex present; bark greyish-white; blaze pale-pink or cream, moderately hard. Stipules 1.5-2 $\times 1$ $\mathrm{cm}$, triangular, entire along margin, acute at apex, coriaceous in texture, minutely pubescent outside, glabrous inside. Leaves spirally-alternate, 11-35; lamina 14-27 × 10-17 cm, ovate, elliptic or suborbicular, rounded or subcordate at base, entire along margin, obtuse at apex, pubescent when young, glabrous above and glabrous or minutely pubescent beneath at maturity, puberulous along margin; mid vein prominent and reaches up to apex, basal nerve $3-7$, reaches up to $1 / 3$ to $1 / 2$ of the lamina,

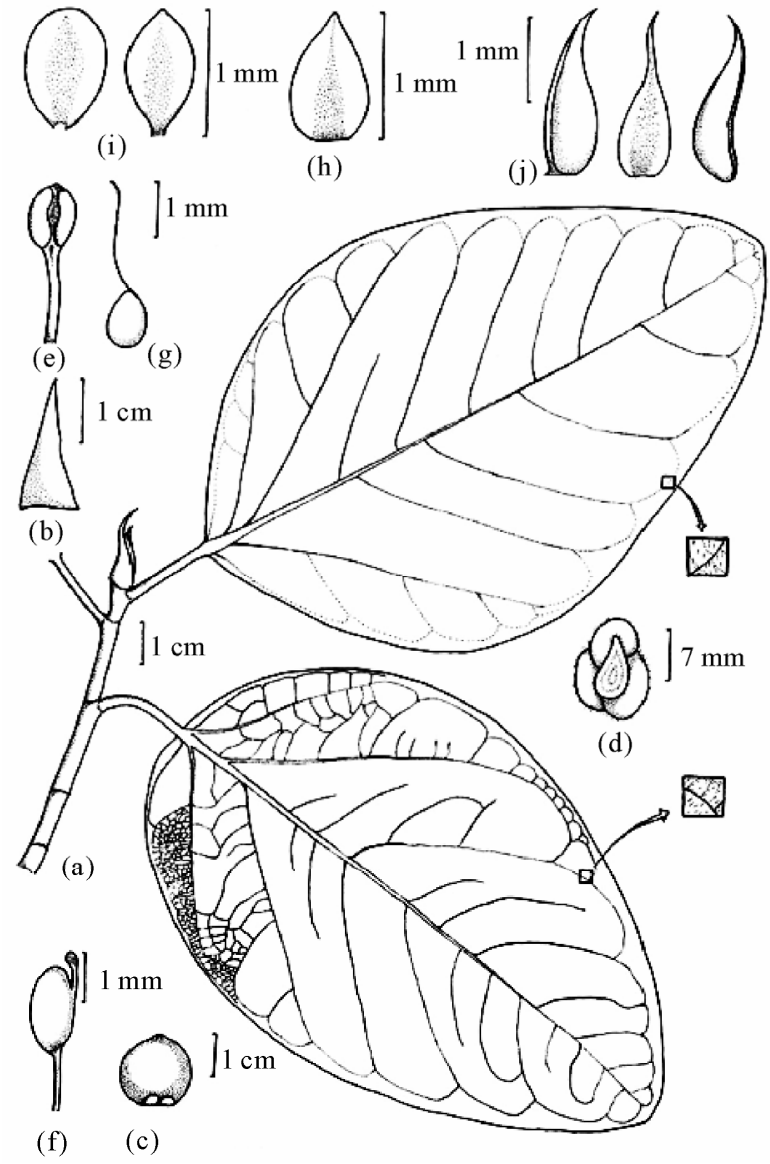

Figure 2. Ficus benghalensis L.: (a) Habit; (b) Stipule; (c) Fig; (d) Basal bract (inside view); (e) Male flower; (f) Gall flower; (g) Female flower; (h)-(j) Tepals (a)-(b) \& (d)-(j) from Chaudhary, Kumar \& Bajpai 252810; c from Chaudhary, Kumar \& Bajpai 250258).

secondary nerves 5-7 pairs, generally forked towards margin; reticulations distinct on both sides; petioles 3-5 $\mathrm{cm}$ long, stout, generally pubescent. Basal bracts 3, 14-17 × 6-13 mm, almost concealed, ovate to rounded, truncate or suborbicular at base, entire along margin, acute or obtuse to round at apex, pubescent at outside, glabrous or minutely pubescent at inside. Fig body sessile, axillary, in pairs, globose, $1-1.5 \times 1.5-2 \mathrm{~cm}$, puberulous, red when ripe. Interfloral bracts 1-3 mm long, club or slightly triangular in shaped, flat, entire along margin, obtuse to acute apex. Male flowers distributed throughout, 2-4 mm long; pedicel ca. 2-3 mm long, glabrous; tepals $3,1 \times 1 \mathrm{~mm}$, broadly ovate to elliptic, entire along margin, acute to obtuse at apex, glabrous, anthers slightly mucronal. Gall flowers ca. $4 \mathrm{~mm}$ long; pedicel ca. 2-3 mm long; tepals 4, 1-2 $\times 1 \mathrm{~mm}$, ovate to elliptic, rounded or oval at base, entire along margins, acute at apex, glabrous; ovary sessile or subsessile, pyriform; style subterminal or lateral, minute; stigma clavate. $\mathrm{Fe}$ - 
male flowers ca. 2-4 mm long, mostly sessile; tepals 3, 1-2 x $1 \mathrm{~mm}$, elliptic to ovate, broadly ovate at base, entire along margins, acute to acuminate at tip, glabrous; ovary sessile, ovoid or pyriform; style 1.5-2 mm long, subterminal; stigma normal or clavate.

Flowering \& Fruiting: Apr. - Jun.

Distribution: India (Planted or running wild throughout), Bangladesh, Nepal, Pakistan, Sri Lanka. Introduced and widely cultivated in tropics and elsewhere.

Uses: The root fibres are given in gonorrhoea. The milky juice is useful in piles, diseases of nose and gonorrhoea. This is also externally applied for pains and bruises, in rheumatism, to cracked or inflamed soles of the feet, to the teeth and gums as a remedy for toothache and for the skin diseases. The tender ends of the hanging roots are given for obstinate vomiting. The aerial root is useful in gonorrhoea, syphilis, biliousness, dysentery and inflammation of the liver. The infusion of the bark is supposed to be a powerful tonic and is considered to have specific properties in the treatment of diabetes and infusion of small branches is useful in haemoptysis. The leaves are good for ulcers and leprosy (Kirtikar \& Basu [15]). The leaves are commonly used as fodder for elephant (Srivastava [16]). The Aerial pillar roots are durable under water and used as well-curbs (Fischer [14]).

Specimens examined: Uttar Pradesh, Bahraich, Katerniaghat Wildlife Sanctuary, Rampurva rest house, 09. 12. 2008, L. B. Chaudhary \& A. Kumar 250111 (LWG); Gangapur village, 22. 02. 2009, L. B. Chaudhary \& A. Kumar 250258 (LWG); Near Kakraha rest house, 21. 07. 2010, L. B. Chaudhary, A. Kumar \& O. Bajpai, 252810 (LWG); Nishanghara forest, 12. 11. 2002, S. D. Maliya 224660 (LWG); Murtiha forest 24. 04. 2003, S. D. Maliya 214829 (LWG).

\subsection{Ficus Heterophylla}

L.f., Suppl. Pl. 442. 1781; Roxb., Fl. Ind. 3: 532. 1832; Wight, Icon. Pl. Ind. Orient. 2: t. 659. 1843; Brandis, For. Fl. N. W. \& C. India 424. 1874 \& Indian Trees 606. 1906; King in Ann. Roy. Bot. Gard. Calcutta. 1: 75, t. 94.1888 \& in Hook.f., Fl. Brit. lndia 5: 518. 1888; Cooke, Fl. Bombay Pres.152. 1907; Kanjilal, For. Fl. Siwalik \& Jaunsar For. Div. United Prov. Agra \& Oudh 373. 1911; Duthie, Fl. Upp. Gang. Pl. 3(1): 154. 1915, p. p. (excl. F. repens Willd.); Haines, Botany of Bihar \& Orissa 876. 1922; Fischer in Gambles, Fl. Pres. Madras 1366. 1928, p. p. (excl. F. repens Willd.); Kanjilal, For. Fl. For Pilibhit, Oudh, Gorakhpur \& Bundelkhand 364. 1933; Corner in Gard. Bull. Singapore 21: 73. 1965 \& in Dass. \& Forsb., Rev. Handb. Fl. Ceylon 3: 272, f. 24. 1981; Srivastava, Fl. Gorakhpurensis 306. 1976; Singh, Fl. Dudhwa National Park 391. 1997; Berg \& Corner in Fl. Malesiana 17(2): 231. 2005; Saini in J. Econ. Taxon. Bot.
29 (4): 878. 2005; Maliya \& Datt in J. Econ. Taxon. Bot. 34 (1): 63. 2010, p. p. (excl. F. repens). F. grossularioides Burm.f., FI. Ind. 227. 1768; O. Kuntze, Rev. Gen. Pl. 1: 626. 1891 p. p.. F. cannabina Lour., Fl. Cochinch. 2: 668. 1790; King in Ann. Roy. Bot. Gard. Calcutta 1: 180. 1888. F. scabrella Roxb., Fl. Ind. 3: 532. 1832; Wight, Icon. Pl. Ind. Orient. 2: t. 661. 1843. F. subpanduraeformis Miq., in Hook. London J. Bot. 7: 235. 1848 \& Ann. Mus. Bot. Lugd.-Bat. 3: 292. 1867. F. heterophylla var. scabrella (Roxb.) King in Ann. Roy. Bot. Gard. Calcutta. 1: 46, t. 94. 2. 1888 \& in Hook.f. Fl. Brit. India 5: 519. 1888, Brandis, Indian Trees 606. 1906. F. heterophylla f. scabrella (Roxb.) King in Hook.f., Fl. Brit. India 5: 519. 1888.

Straggling shrubs. Stem 1-2 m long, woody, supporting themselves among bushes, $10-20 \mathrm{~mm}$ in diam, narrowly hollow, branched, scabrous in young stage, scabrous to glabrous at maturity, internodes $1.5-4.5 \mathrm{~cm}$ long. Stipules $0.7-1 \mathrm{~cm}$ long, deciduous oblong-lanceolate, glabrous. Leaves alternate, $6.3-10.8 \mathrm{~cm}$ long; lamina 5.8$10 \times 1.6-3.6 \mathrm{~cm}$, quite variable, simple to 6-lobed, oblong, lanceolate, elliptic or subobovate, cuneate or obtuse at base, serrate to subentire along margins, acute to sub-

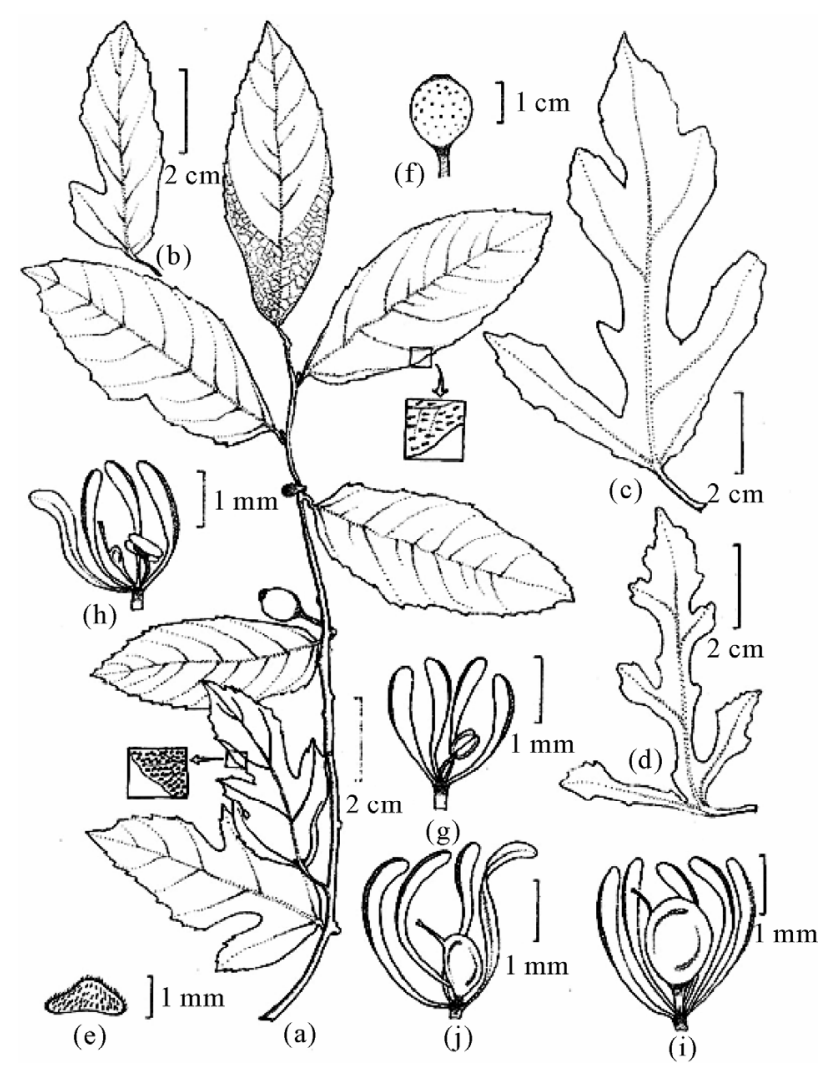

Figure 3. Ficus heterophylla L. f.: (a) Habit; (b)-(d) Leaves; (e) Basal bract; (f) Fig; (g) Male flower; (h) Pistillode flower; (i) Gall flower; (j) Female flower (a)-(b), (e)-(j) from Chaudhary, Kumar \& Bajpai 250629; (c)-(d) from Maliya 225979). 
acuminate at apex, subcoriaceous, scabridulus to prominently scabrid on both sides; midrib reaches up to apex, more hairy on upper surface, basal veins mostly 2, reaches up to $1 / 3$ of lamina, almost equally prominent on both surfaces, secondary veins 4-6 pairs; waxy glands present at the base of the lateral veins and midrib; petioles 5-10 mm long, scabrous. Receptacles $2.3-3 \mathrm{~cm}$ long, axillary, solitary, dioecious; peduncle 1.2-1.8 cm long, scabrous. Basal bracts 3 , ca. $1 \times 2 \mathrm{~mm}$, entire and hairy along margins, obtuse at apex, scabrous outside, glabrous inside. Fig body 1.1-1.2 × 0.8-1.0 cm, ellipsoid or globular, scabridulus to prominently scabrid, yellow or orangeyellow; stipe 0-3 mm long, scabrous. Apical bracts 5, ca. $1 \times 1 \mathrm{~mm}$, free, triangular, entire along margins, acute to obtuse at apex, scabrous outside, glabrous inside. Male flowers in 2-3 rings near the ostiole; pedicel ca. $1 \mathrm{~mm}$ long; tepals 3 (-4), ca. 2-3 mm long, linear-oblong to obovate, entire along margins, obtuse at apex; stamen 1 , ca. $2 \mathrm{~mm}$ long; filament 1, ca. $1 \mathrm{~mm}$ long; anther 1, ca. 1 $\mathrm{mm}$ long. Pistillode flowers present near to mouth of the receptacle, numerous, $2-3 \mathrm{~mm}$ long, with ca.1 $\mathrm{mm}$ long pedicel; tepals 3-5, 2-3 mm long, free, obovate, entire along margins, obtuse at apex, glabrous, hyaline; stamen 1, 1-2 mm long; filament ca. $1 \mathrm{~mm}$ long; anther $1 \times 1$ $\mathrm{mm}$; ovary, ca. $1 \times 1 \mathrm{~mm}$, sessile to subsessile, pyriform; style, ca. $1 \mathrm{~mm}$ long, subterminal or lateral; stigma slightly broadened. Gall flowers present throughout, numerous, ca. $3 \mathrm{~mm}$ long; pedicel up to $1 \mathrm{~mm}$ long; tepals 5, ca. $3 \mathrm{~mm}$ long, free, lanceolate-ellip- tic, entire along margins, acute or sometimes obtuse at apex, glabrous; ovary ca. $1.5 \times 1.5 \mathrm{~mm}$, sessile or subsessile, subspherical to oval; style ca. $0.5 \mathrm{~mm}$; stigma simple, slightly broadened. Female flowers inter mixed with gall flowers, few, ca. $3 \mathrm{~mm}$ long; subsessile; tepals 4, hyaline, 2.5-3 mm, free, obovate, entire along margins, obtuse at apex, glabrous; ovary, ca. $1 \times 1 \mathrm{~mm}$, subsessile, ovate to obovate; style ca. $1 \mathrm{~mm}$ long, subterminal, lateral; stigma slightly broadend. Achenes minute, subglobose, subcompressed, tubercled.

Flowering \& Fruiting: Jun. - Aug.

Distribution: India (Throughout the hotter parts from Sub-Himalayan to Southern regions), Sri Lanka, Myanmar, China, Indochina, Malesia.

Ecology: Common in moist grassy lands and also near water bodies like ponds, lakes, rivers.

Uses: The juice of the root is useful in colic pain. The bark of the roots, which is very bitter, is taken for the treatment of cough \& asthma after pulverizing and mixing it with coriander seeds. The extract of the leaves with milk is useful in dysentery. The leaves are also used as sand paper. The fruits are eaten by local people (Duthie [13]; Kirtikar \& Basu [15]).

Notes: The leaves are quite polymorphic in shape, size, lobations of lamina and hairs even on the same plant. They vary from entire to highly dissected up to 6 lobes. The hairs are faintly to very prominently scabrous on different plants. See also F. assamica.

Specimens examined: Uttar Pradesh, Bahraich, Katerniaghat Wildlife Sanctuary: near Vardia Chauki, 08. 06. 2009, L. B. Chaudhary, A. Kumar \& O. Bajpai 250629 (LWG); Katerniaghat forest, 19. 07. 2004, S. D. Maliya 225979 (LWG).

\subsection{Ficus Hispida}

L.f., Suppl. Pl. 442.1782 (1781); King in Ann. Roy. Bot. Gard. Calcutta. 1: 116, t. 154-155. 1888 \& in Hook.f., Fl. Brit. India 5: 522. 1888; Brandis, Indian Trees 606. 1906; Duthie Fl. Upp. Gang. Pl. 3(1): 155. 1915; Corner in Gard. Bull. Singapore 21: 89. 1965 \& in Dass. \& Forsb., Rev. Handb. Fl. Ceylon 3: 277, f. 27. 1981; Panigrahi in Bull. Bot. Surv. India 11 (1 \& 2): 97. 1969; Srivastava, Fl. Gorakhpurensis 306. 1976; Singh, Fl. Dudhwa National Park 389. 1997; Berg \& Corner in Fl. Malesiana 17(2): 426. 2005; Saini in J. Econ. Taxon. Bot. 29 (4): 878. 2005; Maliya \& Datt in J. Econ. Taxon. Bot. 34 (1):63. 2010. Ficus symphytifolia Lam., Encycl. 2, 2: 498. 1788; King in Ann. Roy. Bot. Gard. Calcutta. 1: 184. 1888. F. oppositifolia Roxb., Pl. Coromandel. 2: 14, t. 124. 1798 \& in Fl. Ind. 3: 561. 1832; Wight, Icon. Pl. Ind. Orient. 2: t. 638. 1843; Griff. in Ic. Pl. As. 4: t. 560. 1854; Dalz. \& Gibs., Fl. Bombay 243. 1861. F. scabra Jacq. in Plant. Rar. Hort. Caes. Sehoenbr. 3: 36, t. 315. 1798, (non Forst. f. 1786). F. daemonum Koen. ex Vahl, En. 2: 198. 1806; Roxb., Fl. Ind. 3: 562. 1832; Wight, Icon. Pl. Ind. Orient 2: t. 641. 1843. Sycomorphe roxburghii Miq. in Ann. Sc. Nat. 3, 1: 35. 1844. Covellia oppositifolia (Roxb.) Gasp., Rend. Ac. Sc. Nap. 25: 85, t. S, f. 36-42. 1845; Griff., Ic. Pl. As. 4: t. 560. 1854. Covellia daemonum (Koen. ex Vahl) Miq. in Hook. London J. Bot. 7: 462. 1848; Dalz. \& Gibs., Fl. Bombay 244. 1861. Covellia assamica Miq. in Hook. London J. Bot. 7: 464. 1848. C. courtallensis Miq. in Hook. London J. Bot. 7: 463. 1848. C. dasycarpa Miq. in Hook. London J. Bot. 7: 464. 1848. C. hispida (L.f.) Miq. in Hook. London J. Bot. 7: 462. 1848. C. setulosa Miq. in Hook. London J. Bot. 7: 462. 1848. C. wightiana Miq. in Hook. London J. Bot. 7: 463. 1848. F. prominens Wall. ex Miq. in Hook. London J. Bot. 7: 236. 1848. Ficus courtallensis (Miq.) Baill., Hist. Pl. 6: 176. 1875.

Vernacular name: Gobla, Kath Gular.

Shrub to small tree, 3-4 m long, all parts mostly hispid-pubescent; bark greyish brown; blaze red fibrous with cream coloured latex; young shoots hollow, densely hispid, milky latex present. Stipules 11-13 mm long, triangular, entire along margins, acute to acuminate at apex, hispid outside, glabrous inside, deep grove in length. 


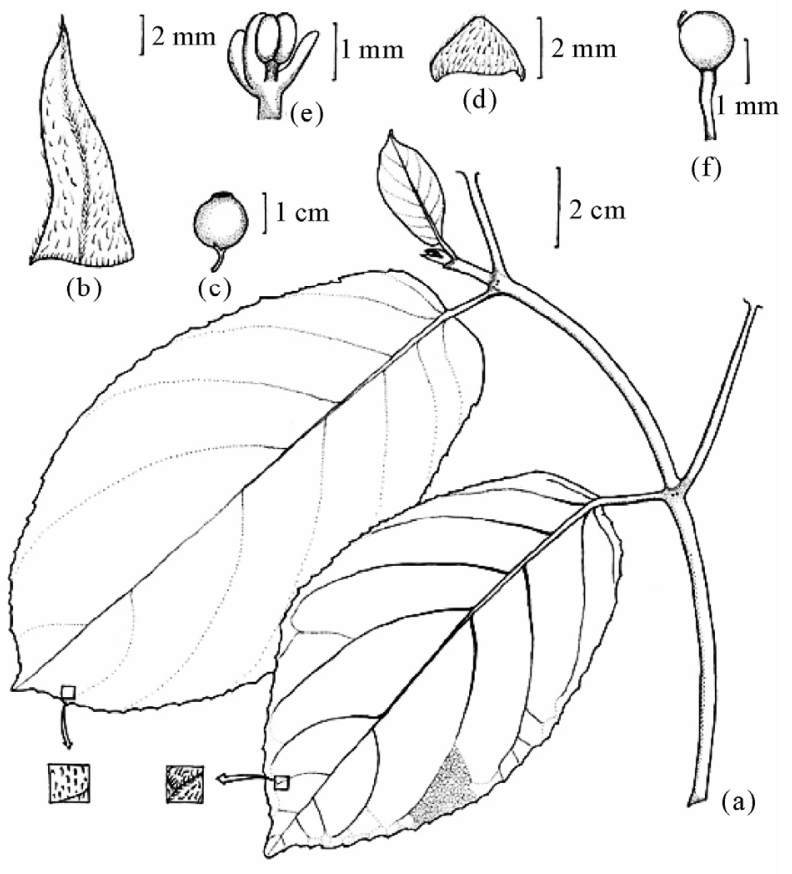

Figure 4. Ficus hispida L. f.: (a) Habit; (b) Stipule; (c) Fig; (d) Basal bract; (e) Male flower; f. Gall flower (a)-(b) \& (d)(f) from Chaudhary, Kumar \& Bajpai 252809; (c) from Chaudhary, Kumar \& Bajpai 250289).

Leaves 10-31 × 7-10 cm, decussate opposite, ovate-oblong, cuneate at base, dentate, denticulate or sometimes entire along margins, hispid-scabrid on dorsal surface, hispid-pubescent on ventral surface; midrib prominent, reaches up to apex; basal veins $2-4$, reaches up to $1 / 3$ of the lamina; secondary veins $4-9$ pairs; petiole $2-6 \mathrm{~cm}$ long, puberulous. Receptacle $2-4.5 \mathrm{~cm}$ long, fascicled on the stem or leafy shortened branchlets from the old wood. Basal bracts 3, 3-4 × 2-3 mm, triangular to elliptic, entire along margins, obtuse at apex, puberulous at outside, scabrous inside. Fig body 1.5-3 × 1.5-2 cm, obovate, subglobose, subspherical or pyriform, hispid, often with scattered bracts, yellowish when ripe; peduncles 0.5-1 $\mathrm{cm}$ long, hispid; stipe 0-5 mm long. Apical bracts many, arranged in a rim covering the apical orifice. Interfloral bracts absent. Male flowers very few near the mouth of the fig, ca. $2 \times 1 \mathrm{~mm}$, sessile to stalked (0-1 mm long); tepals 3, free above, jointed below, obovate or spatulate, entire along margins, obtuse at apex, glabrous; stamen 1 , ca. $2 \mathrm{~mm}$ long, filament 1, ca. $2 \mathrm{~mm}$ long, anther 1, ca. $1 \mathrm{~mm}$ long. Gall flowers numerous, 2-6 mm long; pedicel 2-4 mm long, glabrous, brown in colour; tepals not obvious, adherent to ovary; style minute, subterminal; stigma simple, slightly dilated. Female flowers: Tepals same as gall flowers; style long, lateral, hairy; stigma cylindrical, tubular.

Flowering \& Fruiting: Almost throughout the year.
Distribution: India (Throughout up to 3500 m.), Nepal, Bhutan, China, Indo-china, Sri Lanka, Malaysia.

Ecology: Common in moist and shady habitats.

Uses: Different parts are used in cough, ulcers, biliousness, psoriasis, anaemia, piles, jaundice, haemorrhage of the nose and mouth, diseases of the blood (Kirtikar \& Basu [15]). Figs are considered aphrodisiac and powdered fig paste is applied to buboes. The immature figs are eaten in curries and ripen figs are made into jam (Anonymous [17]). The plants are given to milch cattle to dry up their milk. The leaves and twigs of the plant are used as fodder for cattle and elephants.

Note: Quite variable in the height of the plant, size of leaves and position of fruiting branches, but can easily be identified by its opposite leaves and hollow leafy twigs.

Specimens examined: Uttar Pradesh, Bahraich, Katernighat Wildlife Sanctuary: Nishangara forest, 23. 08. 2002 S. D. Maliya \& Bhaskar Datt 223666 (LWG); Bichhiya town, 18. 04. 2003, S. D. Maliya 242929 (LWG); near Bichhiya town, railway station 27. 08. 2003, S. D. Maliya 214848 (LWG); Karmohini forest, S. D. Maliya 225288 (LWG); near Babhnia Fata village, 22. 02. 2009, L. B. Chaudhary, A. Kumar \& O. Bajpai 250267 (LWG); Rampurva rest house, 08. 04. 2009, L. B. Chaudhary, A. Kumar \& O. Bajpai 250297 (LWG); near Babhnia Fata village, 09. 04. 2009, L. B. Chaudhary, A. Kumar \& O. Bajpai 250289 (LWG); Near Kakraha rest house, 21. 07. 2010, L. B. Chaudhary, A. Kumar \& O. Bajpai 252809 (LWG).

\subsection{Ficus Palmata}

Forssk. subsp. virgata (Roxb.) Browicz in Rechinger, Fl. Iranica 153. 12. 1982; S. Kumar, Fl. Haryana 355. 2001; Abdul Kader in J. Econ. Taxon. Bot. 33: 339-341. 2009. F. virgata Roxb., Fl. Ind. 3: 530. 1832; Wight, Icon. Pl. Ind. Orient. t. 649. 1841. F. caricoides Roxb., Fl. Ind. 3: 529. 1832; Wight, Icon. Pl. Ind. Orient. t. 634. 1841. F. pseudocarica Miq. in Hook. London J. Bot. 7: 225. 1848. F. palmata sensu King in Ann. Bot. Gard. Calcutta 1: 146, t. 185.1888 p. p. (excl. syn. F. pseudo-sycomorus Decne) \& in Hook. f., Fl. Brit. India 5: 530. 1888 p. p. (excl. syn. F. pseudo-sycomorus Decne); Brandis, Indian Trees 607. 1906; Duthie Fl. Upp. Gang. Pl. 3(1): 158. 1915; Collett, Fl. Siml. 460, f. 148. 1921; Corner in Gard. Bull. Singapore 21(1): 36. 1965; Panigrahi in Bull. Bot. Surv. India 11 (1 \& 2): 97. 1969; Nair in Rec. Bot. Surv. India 21(1): 244. 1978; Singh, Fl. Dudhwa National Park 393. 1997; Maliya \& Datt in J. Econ. Taxon. Bot. 34 (1): 63. 2010.

Vernacular name: Anjiri, Bedu, Khemri.

Shrubs or small trees, 1-3 m height. Stem branched, young branches tomentose, old branches glabrous; bark light grey and smooth. Stipules Green-mauve, ca. $2 \times 1$ 


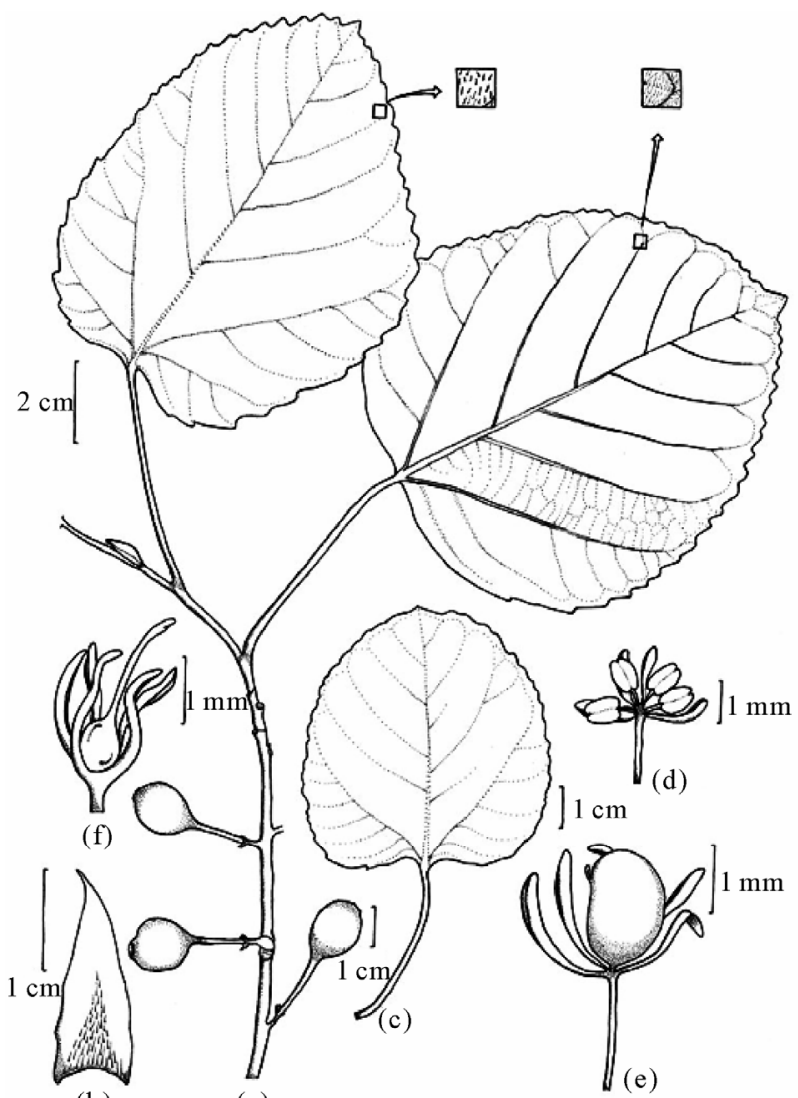

(b)

(a)

Figure 5. Ficus palmata Forssk. subsp. virgata (Roxb.) Browicz.: (a) Habit; (b) Stipule; (c) Leaf; d. Male flower; (e) Gall flower; (f) Female flower (a)-(b) \& (d)-(f) from Chaudhary, Kumar \& Bajpai 252270; c from Chaudhary, Kumar \& Bajpai 250294).

$\mathrm{cm}$, triangular, truncate at base, entire along margins, acute at apex, glabrous except inner basal surface. Leaves 8-18.5 cm, alternate; lamina 5-12.5 × 5-12 cm, broadly ovate, cordate at base, serrate along margins, acute to obtuse at apex, scabrous above, tomentose below, subcoriaceous in texture, midrib single, reaches up to apex, prominent on both sides; basal veins 3-7, reaches up to $1 / 3$ to half of the lamina; secondary veins 5-8 pairs; petiole 3-6 cm long, puberulous. Receptacles 2-2.5 cm long, axillary, solitary; peduncle 3-5 mm long, tomentose. Basal bracts 3, ca. $2 \times 1.6 \mathrm{~mm}$, triangular, entire along margins, acute at apex, tomentose outside towards base, glabrous inside. Fig body 10-14 × 8-15 mm, pyriform, tomentose when young, glabrous at maturity, yellow or purple when ripe; stipe ca. $1.5 \mathrm{~cm}$ long, tomentose. Apical bracts ca. 7, ca. $1.8 \times 1.1 \mathrm{~mm}$, triangular, entire along margins, acute at apex, glabrous inside. Internal hairs present, hyaline. Male flowers numerous, throughout fig body, chiefly near to ostioler opening, ca. 3-4 mm long; pedicel 2-3 mm long; tepals 3-4, 1-1.5 mm long,

hyaline, narrowly obovate, free, minutely hairy along margins, acute at apex,; stamens 3-5, ca. $1.5 \mathrm{~mm}$ long, free; filaments $0.3-0.5 \mathrm{~mm}$ long; anther 1 on each filament, ca. $1 \mathrm{~mm}$ long. Gall flowers numerous, throughout the fig body, ca. $3.5 \mathrm{~mm}$ long, pedicel, ca. $2 \mathrm{~mm}$ long; tepals 5, free, 2-3 mm long, linear-lanceolate, minutely hairy along margins, acute at apex, hyaline; ovary, ca. $1.5 \mathrm{~mm}$ long, ovoid, subsessile; style, minute, lateral; stigma simple with slightly broadend tip. Female flowers 5-6 mm long, pedicel, ca. 2 mm long; tepals 5, 2.5-3 mm long, gamophyllous at base, linear-lanceolate, minutely hairy along margins, acute at apex, hyaline; ovary, 1-1.5 x $1 \mathrm{~mm}$, pyriform to ovoid, subsessile; style up to $2 \mathrm{~mm}$ long, hairy, sub-terminal; stigma unequally bifid.

Flowering \& Fruiting: June - October.

Distribution: India (North - West region: from plains to $1700 \mathrm{~m}$ in the Himalaya; Northern region: Uttar Pradesh, Bihar, Orissa, Madhya Pradesh, Rajasthan; Southern region: Andhra Pradesh, Kerala), Iran, Arabian Peninsula, Afghanistan, Pakistan, Nepal, Somalia, Sudan, Ethiopia and S. Egypt.

Uses: The figs are demulcent and laxative. They are mostly used as diet in cases of constipation and in diseases of the lungs and bladder. They are also used as poultices (Kirtikar \& Basu [15]). It is a goods source of fodder for cattle.

Note: Quite common and variable in height of the plants and leaf shape and size. The typical F. palmata Forssk. occurs in E. Africa and Saudi Arabia. The Indian materials belong to subsp. virgata (Roxb.) Browicz. The species closely resembles with F. carica (Linn.) which is sometimes cultivated in India for fruits.

Specimens examined: Uttar Pradesh, Bahraich, Katerniaghat Wildlife Sanctuary: Jai Rampurva, Motipur, 09. 02. 1965, O. P. Mishra 7755 (BSA); Nishangara forest, 23. 08. 2002, S. D. Maliya 223662 (LWG); Karmohini forest, 16. 03. 2004, S. D. Maliya (LWG); Near Katerniaghat Barrier, 08. 04. 2009, L. B. Chaudhary 250294 (LWG); Nishangarha range, near Bhainsa Lotan Fata village, 24. 04. 2010, L. B. Chaudhary, A. Kumar \& O. Bajpai 252270 (LWG).

\subsection{Ficus Racemosa}

L., Sp. pl. 1060. 1753; King in Ann. Roy. Bot. Gard. Calcutta. 1: 183. 1888; Corner, Gard. Bull. Singapore 21: 34. 1965 \& in Dass. \& Forsb., Rev. Handb. Fl. Ceylon 3: 267, f. 21. 1981; Panigrahi in Bull. Bot. Surv. India. 11 (1\&2): 97. 1969; Srivastava, Fl. Gorakhpurensis 307. 1976; Singh, Fl. Dudhwa National Park 394. 1997; C.C. Berg \& Corner in Fl. Malesiana 17(2): 339. 2005; Saini in J. Econ. Taxon. Bot. 29 (4): 878. 2005; Maliya \& Datt in J. Econ. Taxon. Bot. 34 (1): 63. 2010; Upadhyay \& Srivastava in Taxon 59 (6): 1881, f. 1 \& 3. 2010. F. 


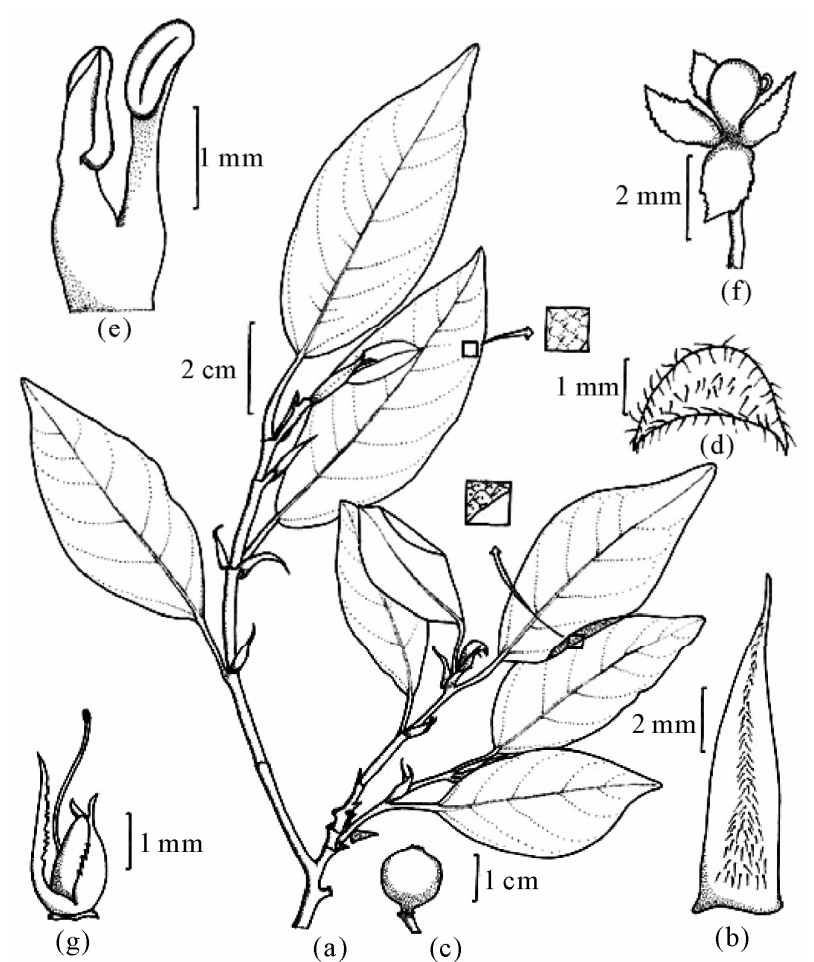

Figure 6. Ficus racemosa L.: (a) Habit; (b) Stipule; (c) Fig; (d) Basal bract; (e) Male flower; (f) Gall flower; (g) Female flower (Chaudhary, Kumar \& Bajpai 250270).

glomerata Roxb., Pl. Coromandel. 2: 13, t. 123. 1798; Wight, Icon. Pl. Ind. Orient. 2: t. 667. 1843; King in Ann. Roy. Bot. Gard. Calcutta. 1: 173, t. 218. 1888 \& in Hook.f., Fl. Brit. India 5: 535. 1888; Brandis, Indian Trees 609. 1906; Duthie, Fl. Upp. Gang. Pl. 3 (1): 160. 1915. Corner in J. Mal. Br. R. As. Soc. 11: 58, f. 31-32. 1933. Covellia glomerata (Roxb.) Miq. in London J. Bot. 7: 465. 1848. F. goolerea Roxb., Fl. Ind. 3: 538. 1832.

Vernacular name: Umar, Gular

Trees, ca. $30 \mathrm{~m}$ tall. Stem profusely branched, with thick, brownish-grey bark; young shoots faintly scabrid. Stipules 10-15 x 3-5 mm long, deciduous, triangular, entire along margins, acute at apex, pubescent outside, glabrous inside. Leaves 9-22 cm long, alternate; lamina $6-14 \times 3.5-8 \mathrm{~cm}$, elliptic to ovate, rounded or cuneate at base, entire along margins, acute at apex, pubescent both sides; mid vein prominent; basal vein 1 pair, reaches up to $c a$. 1/3 of lamina; secondary veins $4-8$ pairs; reticulation distinct; petiole $1.5-6 \mathrm{~cm}$ long, minutely pubescent when young, becoming brown and scurfy at age. Receptacles clustered on up to $25 \mathrm{~cm}$ long leafless branchlets on main trunk and branches; peduncle $c a .1 \mathrm{~cm}$ long, pubescent; puberulous when young. Basal bracts 3, green, greenish pink or mauve, $2-3 \times 2 \mathrm{~mm}$, triangular or broadly ovate, obtuse to rounded at apex, pubescent outside, glabrous inside. Fig body 35-50 mm across, sub- globose, pyriform to subobovate, pubescent, reddish after ripening; ostiole plane or slightly sunken, closed by 5-6 apical bracts, the mouth is occupied by rows of bracts; stipe up to $7 \mathrm{~mm}$ long, pubescent. Male Flowers ca. 3 $\mathrm{mm}$ long, ostioler, in 2-3 rings, sessile; tepals 3-4, membranous, completely envelop the stamens; stamens 2; the filaments united at base, length $c a .2 \mathrm{~mm}$; anther ovate. Gall Flowers distributed everywhere in syconium, 4-5 mm long; stalk 2-3 mm long; tepals 4, ca. $2 \mathrm{~mm}$ long, ovate to elliptic, jointed below, free above, dentate-lacerate along margins, acute to minutely acuminate at apex; ovary rough; style short, lateral; stigma clavate. Female Flowers ca. $4 \mathrm{~mm}$ long, sessile or very minutely stalked; tepals 3, 2-3 mm long, jointed at base, lanceolate, irregularly dentate and clefted along margins, acute to acuminate at tip; ovary sessile, red spotted; style 1-2 mm long, subterminal; stigma clavate.

Flowering \& Fruiting: Mar. - Jul.

Distribution: India (Throughout up to low hills), Nepal, China, Bangladesh, Myanmar, Sri Lanka, Indochina, Pakistan, Malaysia, Australia.

Uses: Root is useful in hydrophobia, dysentery and diabetes. The bark is used in asthma and piles and as a wash for wounds also. The unripe fruit is useful in cough, biliousness, leucorrhoea and blood diseases. The ripe fruit is useful in blood diseases, biliousness, burning sensations, fatigue, urinary discharges, thirst, leprosy, menorrhagia, nose bleeding, chronic bronchitis, dry cough, loss of voice, diseases of the kidney and spleen and in the preparation of cold jelly. The milk is aphrodisiac and vulnerary and used in inflammations, also administered in piles and diarrhoea and in combination with sesame oil in cancer (Kirtikar \& Basu, [15]). The leaves are chopped and given to cattle and elephant as fodder. Wood is not durable but used as well curbs as well as in doors, cross pieces for carts, rice mortars, matchboxes (Anonymous [17]).

Notes: On the basis of shape and pubescence nature of leaves King [7] has identified four varieties in F. glomerata (viz. var. chittagonga (Miq.) King, var. miquelii King, var. mollis (Miq.) King, and var. elongata King). Due to pubescent nature of leaves at both sides the examined specimens belong to var. mollis (Miq.) King, while Brandis [18], Duthie [13] and Corner [19] have not discussed about these varieties in their work. Recently, Upadhyay \& Srivastava [20] have selected the epitype for $F$. racemosa and correctly pointed out that F. glomerata was described by Roxburgh [21] and not by Willdenow [22].

Specimens examined: Uttar Pradesh, Bahraich, Katerniaghat Wildlife Sanctuary: Kakraha rest house, 19. 02. 2009, L. B. Chaudhary \& A. Kumar 250255 (LWG); Babhnia Fata village, 22. 02. 2009, L. B. Chaudhary \& A. 
Kumar 250260 (LWG); Semal chowk, Taratal piller no. 76, 23. 02. 2009, L. B. Chaudhary \& A. Kumar 250270 (LWG); Near Geruva River, Katiyara road, 15. 06. 2009, L. B. Chaudhary, A. Kumar \& O. Bajpai 250608 (LWG); Nishangarha range office, 21. 07. 2010, L. B. Chaudhary, A. Kumar \& O. Bajpai 252808 (LWG).

\subsection{Ficus Religiosa}

L., Sp. pl. 1059. 1753; Wight, Icon. Pl. Ind. Orient. 6: t. 1967. 1853; King in Ann. Roy. Bot. Gard. Calcutta 1: 55, t. 67a. 1887 \& in Hook.f., Fl. Brit. India 5: 513. 1888; Brandis, Indian Trees 601. 1906; Duthie, Fl. Upp. Gang. Pl. 3 (1): 150. 1915; Corner in Gard. Bull. Singapore 21 (1): 6. 1965 \& in Dass. \& Forsb., Rev. Handb. Fl. Ceylon 3: 236. 1981; Srivastava, Fl. Gorakhpurensis 307. 1976; Singh, Fl. Dudhwa National Park 391. 1997; C.C. Berg \& Corner in Fl. Malesiana 17(2): 608. 2005; Saini in J. Econ. Taxon. Bot. 29 (4): 879. 2005; Maliya \& Datt in J. Econ. Taxon. Bot. 34 (1): 64. 2010. Urostigma religiosum (L.) Gasp., Ric. Caprifico 82, t. 7. f. 1-5. 1845; Wight, Icon. Pl. Ind. Orient. t. 1967. 1853. U. affine Miq. in Hook. London J. Bot. 6: 564. 1847. Ficus affinior Griff., Notul. Pl. Asiat. 4: 392. 1854 \& Icon. Pl. Asiat. t. 553. 1854.

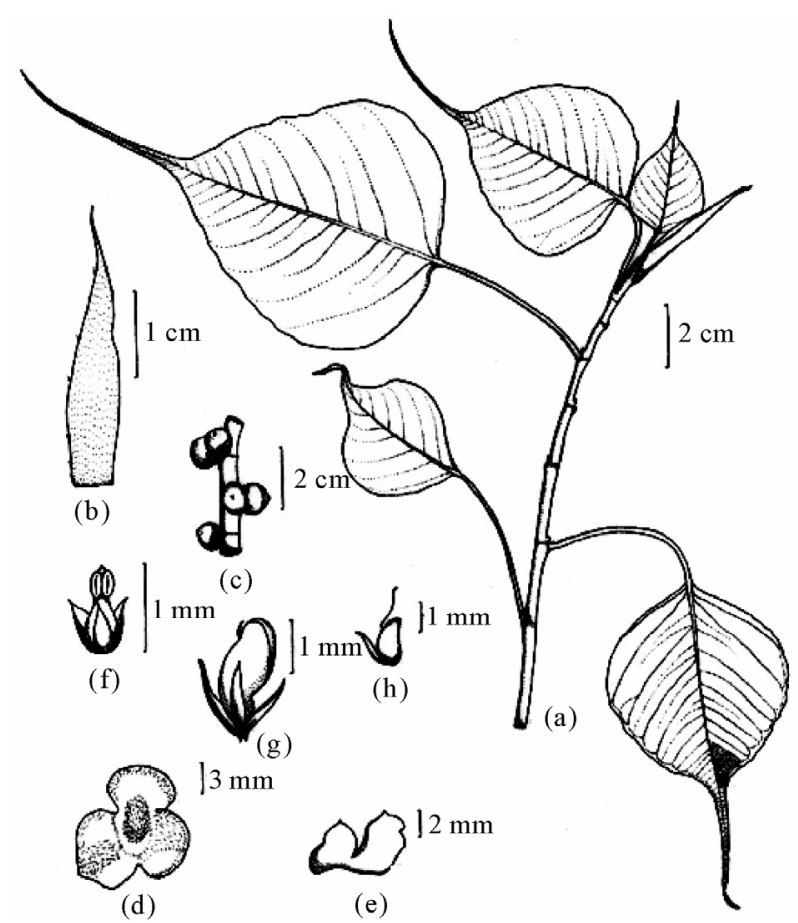

Figure 7. Ficus religiosa L.: (a) Habit; (b) Stipule; (c) A portion of inflorescence axis; (d) Inner basal bract; (e) Outer basal bract; f. Male flower; g. Gall flower; (h) Female flower (a)-(b) \& )d)-(h) from Chaudhary, Kumar \& Bajpai 252807; c from Chaudhary, Kumar \& Bajpai 252107).
Vernacular name: Pipal.

Trees, 7-10 m tall, evergreen, without aerial roots, milky latex present; bark ashy-grey, smooth when young, exfoliating in irregular plates and darken when old; blaze reddish white with lighter bands excluding latex; wood whitish, moderately hard, young twigs \& branches puberulous to densely puberulous. Stipules 25-51 × 4-7 mm, deciduous, elliptic, entire along margins, acute to acuminate at apex, sometimes minutely puberulous along margins otherwise glabrous. Leaves pendulous, pink in young stage, 24-30 cm long, spirally arranged; lamina 15-18 $\times$ 6-12.5 cm, broadly ovate, truncate or subcordate at base, slightly undulate along margins, 3-4.5 cm long caudate at apex, glabrous, subcoriaceous, shiny; mid rib prominent at both surfaces, reaches up to apex, basal veins 3-5, reaches up to $1 / 4$ of the lamina, secondary nerves $8-10$ pairs, reticulations fine and distinct on both surfaces; petioles 9-12.5 cm long, glabrous throughout in young stage, pubescent towards base and glabrous towards apex at maturity. Basal bracts 4, in two rows, 1 in outer row, 3 in inner row; outer bract ca. $5 \times 7 \mathrm{~mm}$, mostly bilobed, entire along margins, acute or obtuse at apex, pubescent outside, glabrous inside; inner bracts 5-6 × $6 \mathrm{~mm}$, adherent to the fig body, elliptic to ovate or suborbicular, jointed at base, entire along margins, obtuse at apex, unevenly pubescent outside, glabrous inside. Fig body axillary, in pairs, sessile, 1-1.5 cm across, globose with depression, glabrous, red when ripe. Apical bracts 3, ca. $2 \times$ $2 \mathrm{~mm}$, covering the ostiole, almost orbicular, mostly white in colour, glabrous. Male flowers very few near ostiole, ca. $1 \times 1 \mathrm{~mm}$, sessile; tepals 3, free, ca. $1 \times 1 \mathrm{~mm}$, elliptic, entire along margins, acute at apex, glabrous; stamen 1, filament minute; anther 1 with two lobes. Gall flowers numerous, throughout inside fig, 2 x $1 \mathrm{~mm}$, sessile or pedicellate; tepals 4-5, free, ca. $1 \mathrm{~mm}$ long, linear - lanceolate, entire along margins, acute at apex, glabrous; ovary ca. $2 \times 1 \mathrm{~mm}$, yellowish; style minute, subterminal; stigma simple. Female flowers 2 x 1-2 mm, mixed with gall flowers, sessile or pedicellate; tepals 4, free, ca. $1 \mathrm{~mm}$ long, linear-lanceolate, entire along margins, acute at apex; ovary pyriform, ca. $2 \times 1 \mathrm{~mm}$; style ca. $1.5 \mathrm{~mm}$ long, subterminal; stigma simple or clavate.

Flowering \& Fruiting: Almost throughout the year.

Distribution: India (Wild in subhimalayan regions, Bengal, Central provinces; cultivated throughout), Pakistan, Nepal, China, Bangladesh, Myanmar, Indochina, Sri Lanka. Introduced and cultivated elsewhere.

Uses: This is considered as a highly sacred tree in Hindu \& Buddha religions since ancient time and worshiped in different ways at various occasions. The juice of bark is used for the treatment of ulcer, liver, spleen and skin diseases (Kirtikar \& Basu, [15]). The milky latex is used as sealing small holes in tires and hollow or- 
naments. The wood is moderately hard and durable so used in packing materials and in match boxes. The leaves are used as a fodder for elephants and cattle. The leaves and tender shoots are purgative and fruits are laxative. It is planted as an avenue or road side tree.

Notes: King [7] observed that basal bracts are spreading; however, in our specimens they are completely adherent to the fig body and they are 4 in two rows. However, in all previous works only 3 bracts have been observed.

Specimens examined: Uttar Pradesh, Bahraich, Katerniaghat Wildlife Sanctuary: Dharampur, Motipur, 20. 05. 1990, K. K. Khanna 63 (BSA); Kakraha rest house, 24. 10. 2009, L. B. Chaudhary, A. Kumar \& O. Bajpai 252107 (LWG); Kakraha rest house, 21. 07. 2010, L. B. Chaudhary, A. Kumar \& O. Bajpai 252807 (LWG).

\subsection{Ficus Retusa var. Nitida (Thunb.)}

Miq. in Ann. Mus. Bot. Lugd.-Bat. 3: 267. 1867; King in Ann. Roy. Bot. Gard. Calcutta 1: 51, t. 62, 84 p. 7-9. 1887; Duthie, Fl. Upp. Gang. Pl. 3 (1): 149. 1915. F. nitida Thunb., Ficus 10. 1786; Wight, Icon. Pl. Ind. Orient. 2: t 642. 1843. Urosyigma nitidum (Thunb.) Miq. in Hook. London J. Bot. 6: 582. 1847.

Vernacular name: Inger.

Free standing trees or epiphytes, $c a$. $20 \mathrm{~m}$ tall, evergreen, aerial roots few, thin in bunches, 3-4 m long, not touching the ground. Stem profusely branched, greyish white with smooth bark and profuse white milky latex. Leafy twig 3-4 mm thick, solid. Stipules 6-9 × 2-3 mm, deciduous, lanceolate, entire along margins, acuminate, cuspidate at apex, glabrous. Leaves 7.8-9.9 cm long, alternate, spirally arranged, lax; lamina 7-9 × 3-4 cm, elliptic or sometimes obovate, cuneate at base, entire along margins, acute to acuminate with $0.8-1.3 \mathrm{~cm}$ long tip, glabrous; midrib more prominent on ventral surface; lateral veins 6-7 pairs; basal vein 1 pair, reaches up to $c a$. $1 / 4$ or $1 / 2$ of lamina, faintly branched; petioles $0.7-1 \mathrm{~cm}$ long. Basal bracts 3, 2-3 mm long with obtuse apex, persistent, glabrous or finely puberulous along margins. Fig body sessile or subsessile, axillary, in pairs or sometimes solitary, rounded, 6-8 $\mathrm{mm}$ across, glabrous, slightly sunken at orifice, yellowish green, red at maturity. Apical bracts $3, c a .1 \times 1 \mathrm{~cm}$, triangular, entire along margins, acute at apex, unevenly puberulous. Interfloral bracts few, minute, brown. Male flowers few, near the mouth of the receptacle; pedicel 1-1.5 mm long; tepals 3, free, spathulate, entire along margins, rounded to acute at apex, glabrous; stamen 1; filament minute; anther dorsifixed, dithecous. Gall flowers sessile or subsessile; tepals 3, spathulate; ovary ovoid, narrowed at both ends; style subterminal; stigma hooded. Female flowers sessile or subsessile, 1.5-2 mm long; tepals 3 , red with white edges,

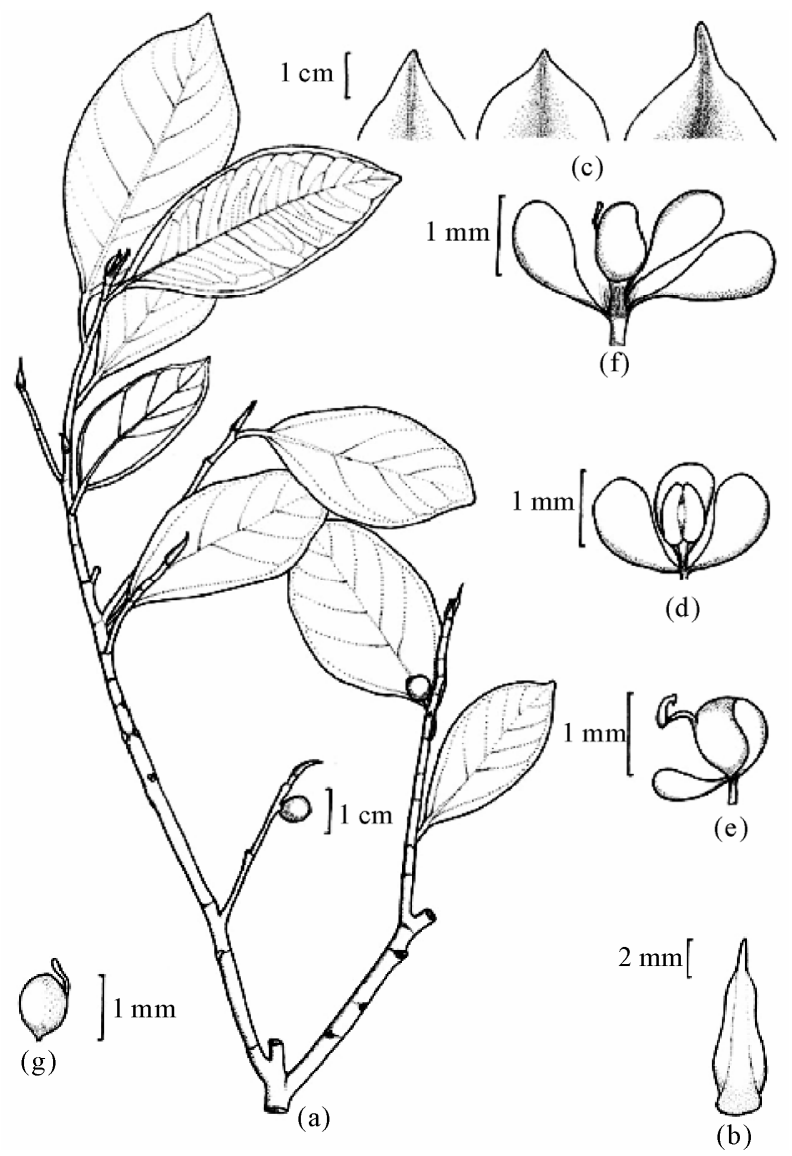

Figure 8. Ficus retusa var. nitida Thunb.: (a) Habit; (b) Stipule; (c) Leaf apices; (d) Male flower; (e) Gall flower; (f)(g) Female flower (a)-(b) \& (d)-(g) from Chaudhary, Kumar \& Bajpai 252104; c from Chaudhary, Kumar \& Bajpai 250257).

spathulate, free; ovary ovoid to obovoid, sessile or sometimes shortly stipitate with few white hairs, mostly with red tinches; style short, subterminal; stigma simple. Achenes ovoid or obovoid, minutely tuberculate.

Flowering \& Fruiting: Almost throughout year.

Distribution: India (North-East region: Assam, Meghalaya-Khasi hills), Myanmar, Malaysia.

Ecology: Dense evergreen tree in association with teak, sal, tendu, asna, rohini etc. Sometimes it grows as epiphyte on tendu plant.

Uses: Latex is used in leprosy \& skin diseases by local people.

Note: Sometimes F. nitida Thunb. is reduced as synonym either under $F$. benjamina L. or F. microcarpa L.f. however, it distinctly differs in the nature of aerial roots, apex of leaf lamina, length of petioles and colour of figs.

Specimens examined: Bahraich, Katerniaghat forest, Behind Kakraha rest house, 24.10.09, L. B. Chaudhary, A. Kumar \& O. Bajpai 252104 (LWG); Behind Kakraha 
rest house, 19.02.09, L. B. Chaudhary, A. Kumar \& O. Bajpai 250257 (LWG).

\subsection{Ficus Rumphii}

Blume in Bijdr. Fl. Ned. Ind. 437. 1825; King in Ann. Roy. Bot. Gard. Calcutta 1: 54, t. 67 b \& 84 t. 1887 \& in Hook.f., Fl. Brit. India 3: 512. 1888; Watt., Dict. Ec. Prod. Ind. 3: 361. 1890; Brandis, Indian Trees 601. 1906; Duthie, Fl. Upp. Gang. Pl. 3(1): 151. 1915; Srivastava, Fl. Gorakhpurensis 307. 1976; Singh, Dudhwa National Park 390. 1997; C.C. Berg \& Corner in Fl. Malesiana 17(2): 609. 2005. Ficus cordifolia Roxb., Fl. Ind. 3: 548. 1832 (non Blume 1825); Wight, Icon. Pl. Ind. Orient. 2: t. 640. 1843; Brandis, For. Fl. N. W. \& C. India 416, t. 48. 1874. F. conciliorum (Rumph.) Oken. in Allg. Naturgesch. 3: 1561. 1841. F. populnea Kunth \& Bouche, Ind. Sem. Hort. Berol. 16. 1846. Urostigma cordifolium (Roxb.) Miq. in Hook. London J. Bot. 5: 564. 1847; Dalz. \& Gibs., Bombay Fl. 242. 1861. U. rumphii (Bl.) Miq. in Zoll. Syst. Verz. 2: 90. 1854. Ficus populiformis Schott. ex Miq. in Ann. Mus. Bot. Lugd.-Bat. 3:287. 1867.

Vernacular name: Pilkhan, Khabar, Gajhar.

Tree, ca. $20 \mathrm{~m}$ tall, epiphytic at beginning. Stem solid, branched, glabrous; bark yellowish grey or brown, smooth; blaze orange red exuding latex. Stipules deciduous, ca. $8 \times 4 \mathrm{~mm}$, triangular, truncate at base, entire along margins, acute at apex, glabrous. Leaves 16.5-23 $\mathrm{cm}$ long, spirally alternate; lamina, 11-15 $\times 7-10 \mathrm{~cm}$, simple, ovate, truncate to rounded at base, entire or subundulate along margins, acuminate at apex, shining above, glabrous, subcoriaceous; midrib prominent on both sides, basal veins 4-5, secondary veins 7-10 pairs; texture; petiole 4-8 cm long; glabrous. Basal bracts 3, ca. 4-5 $\times 2.5-4 \mathrm{~mm}$, triangular, entire along margins, acute to apiculate at apex, coriaceous, glabrous. Fig body axillary, in pairs, sessile, 6-8 × 7-9 mm, rounded without depresssion, green \& glabrous when young, dark reddish black when ripe. Apical bracts 3, ca. $1 \times 1 \mathrm{~mm}$, triangular, acute at apex, closed to each other, glabrous, pale yellow. Interfloral bracts hyaline to brownish, up to $2 \mathrm{~mm}$ long, flat, rectangular to linear-lanceolate, entire along margins, acute to acuminate at apex, glabrous. Male Flowers Near to ostioler opening, very few, $c a$. $2 \mathrm{~mm}$ long; pedicel $c a$. $2 \mathrm{~mm}$ long; tepals 3 , hyaline, $c a .1 .3 \mathrm{~mm}$ long, spatulate, free, entire along margins, obtuse at apex, glabrous; stamen 1, filament, ca. $0.5 \mathrm{~mm}$ long; anther 1, ca. $0.5 \times 0.5$ $\mathrm{mm}$. Gall Flowers throughout fig, numerous, $2-3 \mathrm{~mm}$ long, pedicel, 0.5-0.7 mm long; tepals 3, hyaline, ca. 1 $\mathrm{mm}$ long, spatulate, free, entire along margins, obtuse at apex, glabrous; ovary, $1 \times 0.8 \mathrm{~mm}$, subsessile, ovoid or pyriform; style 1, ca. 1-1.5 mm long, lateral, more than upper half portion hairy; stigma simple. Female Flowers throughout fig, numerous, ca. $3 \mathrm{~mm}$ long; pedicel, ca. 1

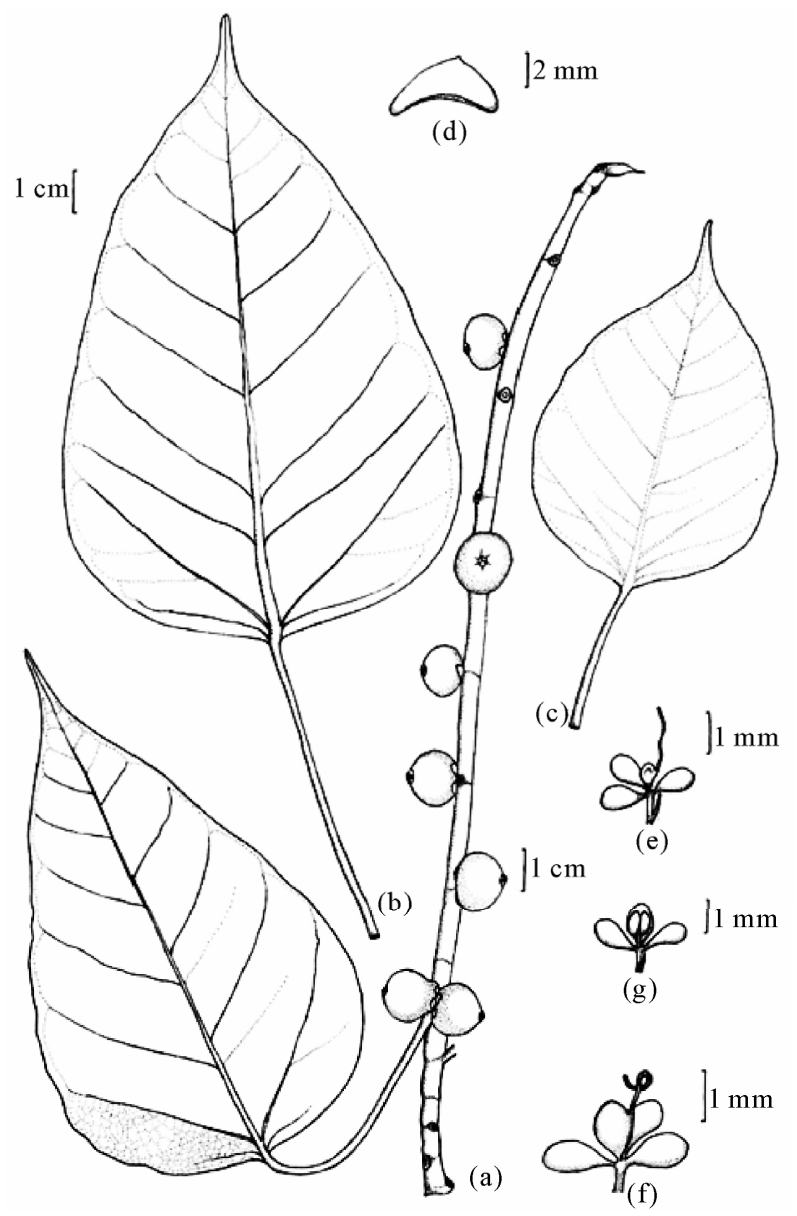

Figure 9. Ficus rumphii Blume: (a) Habit; (b)-(c). Leaves; (d) Basal bract; (e) Male flower; (f)) Gall flower; (g) Female flower (Chaudhary, Kumar \& Bajpai 252818).

$\mathrm{mm}$ long; tepals 3, hyaline, ca. $1 \mathrm{~mm}$, spatulate, free, entire along margins, obtuse at apex, glabrous; ovary ca. $0.5 \mathrm{~mm}$ long; subsessile, pyriform; style ca. $1 \mathrm{~mm}$ long, subterminal or lateral, more than upper half portion hairy; stigma simple.

Flowering \& Fruiting: April - July \& December January.

Distribution: India (North West to North East \& Central provinces, Andaman and Nicobar Island. From subhimalayan tract and outer hills, ascending to $5000 \mathrm{ft}$.), Nepal, Bhutan, China, Myanmar, Indochina, Malaysia.

Uses: The fruit juice mixed with turmeric, pepper and ghee is given internally to kill worms and in asthma (Kirtikar \& Basu [15]). The leaves and twigs are used as a fodder.

Note: Very similar to F. religiosa, but differs in having acuminate apex (vs. abruptly caudate) and undepressed globose figs (vs. depressed globose).

Specimens examined: Uttar Pradesh, Bahraich, Katerniaghat Wildlife Sanctuary: Kakraha rest house, 24. 10. 
2009, L. B. Chaudhary, A. Kumar \& O. Bajpai 252106 (LWG); Kakraha rest house, 22. 10. 2010, O. Bajpai 252818 (LWG).

\subsection{Ficus Semicordata}

Buch.-Ham. ex J. E. Sm. in Rees, Cyclop. 14: Ficus n. 71. 1810; Corner in Gard. Bull. Singapore 17: 449. 1960 \& 21 (1): 62.1965; Singh, Dudhwa National Park 392. 1997; C.C. Berg \& Corner in Fl. Malesiana 17(2): 382. 2005; Saini in J. Econ. Taxon. Bot. 29 (4): 879. 2005; Maliya \& Datt in J. Econ. Taxon. Bot. 34 (1): 64. 2010. F. cunia Buch.-Ham. ex Roxb., Fl. Ind. 3: 561. 1832; Wight, Icon. Pl. Ind. Orient. 2: t. 648. 1843; King in Ann. Roy. Bot. Gard. Calcutta 1: 101, t. 126. 1888 \& in Hook.f., Fl. Brit. India 5: 523. 1888 p.p. (excl. F. conglomerata Roxb. 1832); Brandis, Indian Trees 606. 1906; Duthie, Fl. Upp. Gang. Pl. 3(1): 156. 1915; Corner in J. Mal. Br. R. As. Soc. 11: 21, f. 8, 9. 1933; Srivastava, Fl. Gorakhpurensis 306. 1976. Covellia cunia (Buch.-Ham. ex Roxb.) Miq. in Hook. London J. Bot. 7: 459. 1848. Ficus hapalophylla Kurz., Fl. Burma 2: 461, f. 87. 1877.

Vernacular name: Khini, Khunia, Khain, Khurhur (Hindi).

Medium-sized tree with grayish brown bark; blaze red, fibrous with cream coloured latex. Stipules ca. $35 \times 7$ $\mathrm{mm}$, ovate-elliptic, truncate at base, entire along margins, acute to acuminate at apex, unevenly pubescent outside, glabrous inside. Leaves 13.5-19.5 cm long; lamina 12.5-20.5 × 5.5-5.8 cm, alternate, elliptic, unequally oblique semisagittate at base, serrate along entire margins or sometimes entire up to lower half, pubescent to scabrous below, scabrous above, acute to subacute at apex; mid rib reaches up to apex, comparatively less prominent on upper surface; basal veins $4-6$, reaches up to or less than $1 / 3$ of the leaf lamina; secondary veins 8-10 pairs; petiole 1-1.5 cm long, puberulous. Receptacles ca. $2 \mathrm{~cm}$ long, axillary, single to 3 or sometimes more, born on separate quite elongated branches (up to 6 feet long) develop in clusters near base or in the middle of stem; peduncle 0-7 mm, surface tomentose. Basal bracts 3, ca. $6.2 \times 3 \mathrm{~mm}$, triangular, truncate at base, entire along margins, acute at apex, tomentose outside, glabrous inside. Fig body 7-11 $\times$ 6-10 mm, globose to subglobose, tomentose, brown wart like structures on fig body, light pinkish. Apical bracts many, around orifice, $1-2$ x $3 \mathrm{~mm}$, pointed upwards, triangular in shape, truncate at base, entire along margin, acute at apex, puberulous outside, glabrous inside. Internal hairs absent. Male flowers present near the mouth of the receptacles with 3 lanceolate perianth; stamens with short filament and ovate anther. Gall flowers with 4 perianth united below; ovary globular, smooth; style lateral, very short. Female flowers ca. $2 \mathrm{~mm}$ long, sessile or subsessile; tepals 5, ca.

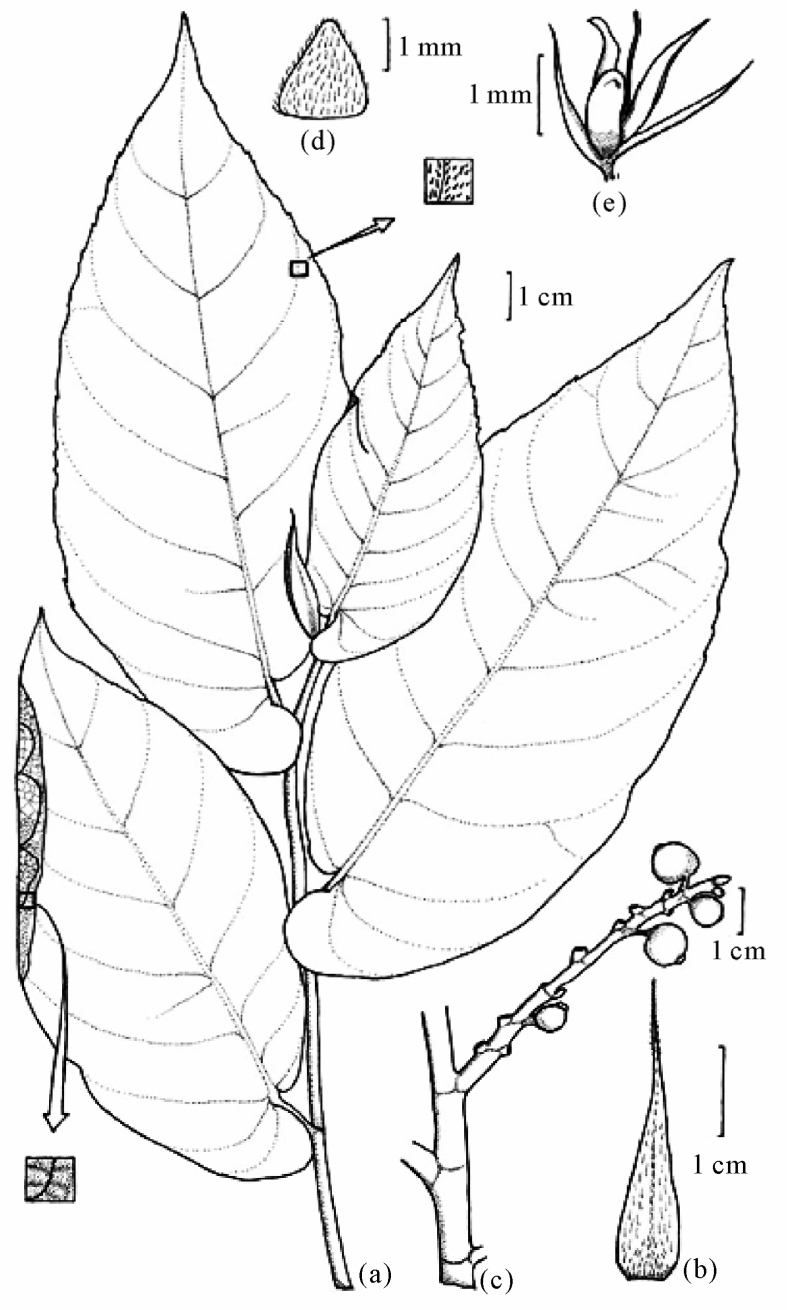

Figure 10. Ficus semicordata Buch.-Ham. ex J.E. Sm.: (a) Habit; (b) Stipule; (c) A portion of inflorescence axis; (d) Basal bract; (e) Female flower (Chaudhary, Kumar \& Bajpai 250290).

$2 \mathrm{~mm}$ long, free, linear-lanceolate, entire along margins, acuminate at apex, glabrous, red to reddish brown, hyaline along margin; ovary ca. $1 \mathrm{~mm}$ long; style $c a .2 \mathrm{~mm}$ long, lateral; stigma simple.

Flowering \& Fruiting: May-Sep.

Distribution: India (North-West \& North-East region (Jammu \& Kashmir, Uttar Pradesh, Jharkhand, Madhya Pradesh, Sikkim, Assam, Meghalaya, Manipur), Pakistan, Nepal, Bhutan, China, Bangladesh, Myanmar, Thailand, Vietnam, Malaysia.

Uses: The figs are sweet and eaten by locals as fruit. A bath made from the fruit and bark is a cure for leprosy. The juice from the roots is given in bladder complaints and visceral obstructions (Kirtikar \& Basu [15]). The fibre of the bark is used in the preparation of rope. The leaves are use as fodder for cattle. 
Specimens examined: Uttar Pradesh, Bahraich, Katerniaghat Wildlife Sanctuary: Miscellaneous forest, Near Balcha Barrier, 09. 04. 2009, L. B. Chaudhary 250290 (LWG); Near Murtiha barrier, 09. 04. 2009, L. B. Chaudhary 250291 (LWG); Sujauli road, near Oripurva village, 31. 10. 2009, L. B. Chaudhary, A. Kumar \& O. Bajpai 252173 (LWG); Sujauli road, near Oripurva village 31. 10. 2009, L. B. Chaudhary, A. Kumar \& O. Bajpai 252174 (LWG).

Note: Very interesting and distinct species in which the fruiting branches born in cluster surrounding the base of the main trunk or in the middle of the trunk.

\subsection{Ficus Squamosa}

Roxb., Fl. Ind. 3: 531. 1832; Wu et al. in Wu et al., Fl. China 5: 49. 2003. F. saemocarpa Miq. in Ann. Mus. Bot. Lugd.-Bat. 3: 232. 1867; King in Ann. Roy. Bot. Gard. Calcutta 1: 115, t. 152. 1888 \& in Hook. f., Fl. Brit. India 5: 523. 1888; Brandis, Indian Trees 606. 1906. F. pyrrhocarpa Kurz., Fl. Brit. Burm. 2: 457. 1832. F. laminosa Hardw. ex Roxb., Fl. Ind. 3: 531. 1832; Duthie Fl. Upp. Gang. Pl. 3(1): 156. 1915.

Bushy shrub or small tree, 4-5 feet long, caespitose, erect. Stem hollow, branched, young twig shows soft pith. Stipules deciduous. Leaves 13.8-38.2 cm long, opposite; lamina 11.7-28 × 7.5-15.2 cm, lanceolate to oblanceolate, truncate at base, serrate along margins, acuminate at apex, scabrous above, strigose below; midrib prominent on both sides, secondary veins 6-10 pairs, basal veins 4-6 reaches up to 1/5-1/4 of lamina; petiole 2.1-10.2 cm long, surface scabrous. Receptacles 3.7-5.2 cm long; develop on panicles with or without leaves coming out from the older parts of the stem \& main branches; peduncle 1.6-2.2 cm long, hispid with brownish hairs. Basal Bracts 3, $1.5 \times 2 \mathrm{~mm}$, triangular, entire \& hairy along margins, obtuse at apex, hispid outside, glabrous inside. Fig body 1.8-2.3 $\times 2-2.5 \mathrm{~cm}$, in pairs, spherical or globose, yellow when ripe, hispid; stipe 5-7 mm long, hispid with brown hairs. Lateral bracts present on fig body, 1-4, 3-5 $\times 2 \mathrm{~mm}$, almost inverted triangular, entire and hispid along margins, truncate at apex, hispid outside, glabrous inside. Apical bracts 3, ca. $3 \times 2 \mathrm{~mm}$, almost triangular, entire and hairy along margins, obtuse at apex, hispid outside, glabrous inside. Interfloral bracts absent. Male flowers with three to four perianth; anther single. Gall flowers perianth hyaline, closely attached to the smooth ovary; style short, lateral; stigma tubular. Female Flowers throughout fig, numerous, $c a$. $3 \mathrm{~mm}$ long, pedicel 0-2 $\mathrm{mm}$ long; tepals closely applied to the ovary; ovary, $0.8-1 \times 0.6-0.8 \mathrm{~mm}$, minutely stipitate, pyriform; style $1-2 \mathrm{~mm}$ long, subterminal to lateral, hairy; stigma simple, slightly broadened, brownish in colour.

Flowering \& Fruiting: Almost throughout the year.

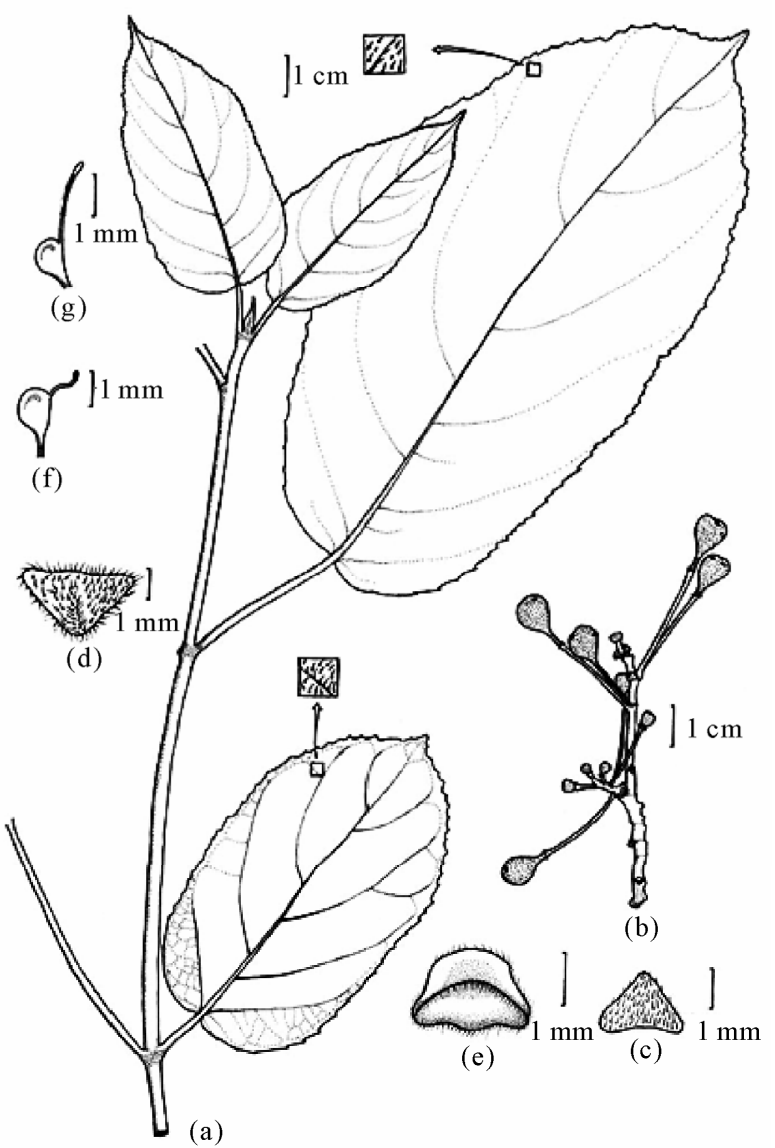

Figure 11. Ficus squamosa Roxb.: (a) Habit; (b) A portion of inflorescence axis; (c) Basal bract; (d) Lateral bract; (e) Apical bract (inside view); (f) Gall flower; (g) Female flower (Chaudhary, Kumar \& Bajpai 252819).

Distribution: India (North \& North-East regions: from foot of the Kumaon Himalaya to eastwards), Nepal, Bhutan, China, Myanmar, Thailand.

Notes: Very allied to F. hispida, but differs in caespitose nature and lateral bracts present on fig body.

Specimens examined: Uttar Pradesh, Bahraich, Katerniaghat Wildlife Sanctuary: Behind Kakraha Rest House, 22. 10. 2009, L. B. Chaudhary, A. Kumar \& O. Bajpai 250700 (LWG); Near Girijapuripuri Petrol Pump, 22. 10. 2010, O. Bajpai 252819 (LWG).

\section{Acknowledgements}

The authors are grateful to Dr. C. S. Nautiyal, Director, National Botanical Research Institute, Lucknow (CSIR) for providing facilities and encouragement. The thanks are also due to the in-charge of herbaria mentioned in the work and to the forest officials of Katerniaghat Wildlife Sanctuary for granting permission and facilities to visit the area. The funds to carry out this work were received 
from CSIR, New Delhi under NWP-020.

\section{REFERENCES}

[1] E. J. H. Corner, “An Introduction to the distribution of Ficus,” Reinwardtia, Vol. 4, 1958, pp. 15-45.

[2] E. J. H. Corner, "Check-list of Ficus in Asia and Australiasia with Keys to Identification,” The Gardens’ Bulletin Singapore, Vol. 21, No. 1, 1965, pp. 1-186.

[3] C. C. Berg, "Classification \& Distribution of Ficus," Experientia, Vol. 45, No. 7, 1989, pp. 605-611. doi:10.1007/BF01975677

[4] C. C. Berg and E. J. H. Corner, “Moraceae-Ficus,” Flora Malesiana Series I (Seed Plants), Vol. 17, No. 2, 2005, pp. 1-727.

[5] N. Rønsted, G. D. Weiblen, W. Clement, N. Zerega and V. Savolainen, "Reconstructing the phylogeny of figs (Ficus, Moraceae) to unravel the origin of fig-wasp mutualisms," Symbiosis, Vol. 45, 2008a, pp. 45-56.

[6] N. Rønsted, G. D. Weiblen, V. Savolainen and J. M. Cook, "Phylogeny, biogeography, and ecology of Ficus section Malvanthera (Moraceae),” Molecular Phylogenetics and Evolution, Vol. 48, 2008b, pp. 12-22. doi:10.1016/j.ympev.2008.04.005

[7] G. King, "The Species of Ficus of the Indo-Malayan And Chinese Countries,” Annals of the Royal Botanic Garden, Calcutta, Vol. 1, 1887-1888, pp. 1-185 (+ i-xiii, i-vi, plates 1-232, 1-52, plates 1-5).

[8] G. King, “Ficus L.,” In: J. D. Hooker, The Flora of British India, L. Reeve \& Co., London, UK., Vol. 5, 1888, pp. 494-537.

[9] S. D. Maliya and Bhaskar Datt, “A Contribution to the Flora of Katerniyaghat Wildlife Sanctuary, Bahraich District, Uttar Pradesh,” Journal of Economic and Taxonomic Botany, Vol. 34, No. 1, 2010, pp. 63-64.
[10] K. K. Khanna, V. Mudgal, B. P. Uniyal and J. R. Sharma, "Dicotyledonous Plants of Uttar Pradesh - A Checklist", Bishen Singh Mahenra Pal Singh, Dehra Dun, 1999.

[11] D. C. Saini, "Flora of Bahraich District, Uttar Pradesh-V," Journal of Economic and Taxonomic Botany, Vol. 29, No. 1, 2005, pp. 878-879.

[12] G. Panigrahi, A. N. Singh and O. P. Mishra, "Contribution to the Botany of the Tarai Forests of the Bahraich District of Uttar Pradesh,” Bulletin of the Botanical Survey of India, Vol. 11, No. 1 \& 2, 1969, pp. 96-97.

[13] J. F. Duthie, "Flora of Upper Gangetic Plain and of the adjacent Siwalik \& Sub-Himalayan Tracts,” Calcutta, Vol. 3 (1), 1915.

[14] C. E. C. Fischer, “Moraceae," In: J. S. Gamble, Flora of Presidency of Madras, Botanical Survey of India, Calcutta, part 8, 1928, pp. 1351-1369.

[15] K. R. Kirtikar and B. D. Basu, "Indian Medicinal Plants," Oriental Enterprises, Dehra Dun, Vol. 10, 2001(2 ed.).

[16] T. N. Srivastava, "Flora Gorakhpurensis", Today \& Tomorrow’s Printer \& Publishers, New Delhi, 1976.

[17] Anonymous, "Wealth of India," CSIR, New Delhi, Vol. 4 (F-G), 1956.

[18] D. Brandis, “Indian Trees,” Archibald Constable 7 Co. Ltd., London, 1906.

[19] E. J. H. Corner, “Moraceae,” In: M. D. Dassanayake, Ed., A Revised Handbook to The Flora of Ceylon, Oxford \& IBH, New Delhi, Vol. 3, 1981, pp. 230-279.

[20] G. K. Upadhyay and S. K. Srivastava, "Lecto- and epitypification of Ficus racemosa L. (Moraceae),” Taxon, Vol. 59, No. 6, December 2010, pp. 1879-1882.

[21] W. Roxburgh, "Plants of the coast of the Coromandel," Bulmer \& Co., London, Vol. 2, 1798.

[22] K. L. Willdenow, “Species Plantarum," Nauk, Berlin, Vol. 4, 1806. 